\title{
Ferromanganese nodule fauna in the Tropical North Pacific Ocean : species richness, faunal cover and spatial distribution
}

\author{
Julie Veillette ${ }^{1, *}$, Jozée Sarrazin ${ }^{2}$, Andrew J. Gooday ${ }^{3}$, Joëlle Galéron ${ }^{2}$, Jean-Claude \\ Caprais $^{2}$, Annick Vangriesheim², Joël Étoubleau ${ }^{2}$, James R. Christian ${ }^{4}$, S. Kim Juniper ${ }^{1,5}$
}

\footnotetext{
${ }^{1}$ Centre GÉOTOP, Université du Québec à Montréal, C.P. 8888, Succursale Centre-Ville, Montréal, Québec H3C 3P8, Canada

${ }^{2}$ Institut Français de Recherche pour l'Exploitation de la MER/ Département Étude des Écosystèmes Profonds, Centre de Brest BP 70, 29280 PLOUZANE, France

${ }^{3}$ National Oceanography Centre, Southampton, University of Southampton Waterfront Campus, European Way, Southampton, SO14 3ZH, UK

${ }^{4}$ Fisheries and Oceans Canada, Canadian Centre for Climate Modelling and Analysis, University of Victoria, P.O. Box 1700, Victoria, British Columbia V8W 2Y2, Canada

${ }^{5}$ Present address : School of Earth and Ocean Sciences, University of Victoria, P.O. Box 3020, Victoria, British Columbia V8W 3N5, Canada
}

*: Corresponding author : Julie Veillette, email address : julie.veillette.2@ulaval.ca

\begin{abstract}
:
The poorly known ferromanganese nodule fauna is a widespread hard substratum community in the deep sea that will be considerably impacted by large-scale nodule mining operations. The objective of this study was to analyze the spatial distribution of the fauna attached to nodules in the ClarionClipperton Fracture Zone at two scales; a regional scale that includes the east $\left(14^{\circ} \mathrm{N}, 130^{\circ} \mathrm{W}\right)$ and the west $\left(9^{\circ} \mathrm{N}, 150^{\circ} \mathrm{W}\right)$ zones and a local scale in which different geological facies (A, B, C and west) are recognizable. The fauna associated with 235 nodules was quantitatively described: 104 nodules from the east zone ( 15 of facies A, 50 of facies B and 39 of facies $C$ ) and 131 nodules from the west zone. Percent cover was used to quantify the extent of colonization at the time of sampling, for 42 species out of the 62 live species observed. Fauna covered up to 18\% of exposed nodule surface with an average of about $3 \%$. While species richness increased with exposed nodule surface, both at the regional and at the facies scales (except for facies $A$ ), total species density decreased (again except for facies A). When all nodules were included in the statistical analysis, there was no relation between faunal cover and exposed nodule surface. Nevertheless, faunal cover did decrease with exposed nodule surface for the east zone in general and for both facies B and C in particular. Species distributions among facies were significantly different but explained only a very small portion of the variance (not, vert, similar5\%). We identified two groups of associated species: a first group of two species and a second group of six species. The other species (34) were independently distributed, suggesting that species interactions play only a minor role in the spatial distribution of nodule fauna. The flux of particulate organic carbon to the bottom is the only major environmental factor considered to vary between the two zones within this study. We conclude that the higher species richness and higher percent faunal cover of the east zone can be partially attributed to greater food availability derived from surface inputs. Moreover, the surfaces of facies $B$ and $C$ nodules had a complex, knobby micro-relief, creating microhabitat heterogeneity that may also have contributed to the greater species richness observed in the east zone.
\end{abstract}

Keywords: Ferromanganese nodules; Fixed fauna; Agglutinated foraminifera; Geographical distribution; Environmental factors; Environmental impacts 


\section{Introduction}

Faunas that encrust ferromanganese nodules are poorly known, even though the hard substratum formed by the nodules is widespread in the deep sea, particularly in the Pacific Ocean where they may cover more than 50\% of the seafloor (Smith and Demopoulos, 2003; Thistle, 2003). Nodules represent a valuable natural resource. However, in order for nodule mining to be economically viable, exploitation will likely be at scales of tens to hundreds of thousands of square kilometres (Glover and Smith, 2003; Thiel, 2003). Among the potential impacts of nodule mining is the destruction of the fauna attached to the nodules (Thiel et al., 1993) and the partial covering of surrounding epifauna by sediment blanketing (Morgan et al., 1999; Sharma et al., 2001; Thiel et al., 2001). In order to manage and mitigate these impacts, it is critical that we better understand the composition and distribution of the nodule fauna and its relationship to the mineral substratum and other environmental factors.

The study of hard substratum communities in nodule fields has been neglected compared to adjacent sediment communities, probably because of the difficulties inherent in remotely sampling nodules from the sea surface. Most previous studies of nodule faunas focused on their role in nodule formation and growth (Graham and Cooper, 1959; Ehrlich, 1972; Dudley and Margolis, 1974; Greenslate et al., 1974; Wendt, 1974; Dudley, 1976; Dugolinsky, 1976; Dugolinsky et al., 1977; Dudley, 
1978; Thiel, 1978; Bignot and Lamboy, 1980; Riemann, 1983; von Stackelberg, 1984; Riemann, 1985; Thiel et al., 1993). The bacteria associated with nodules (Ehrlich, 1972; Burnett and Nealson, 1981) and the fauna found within nodule crevices have been examined (Thiel et al., 1993; Maybury, 1996), but the only detailed ecological study of organisms living on nodule surface was conducted by Mullineaux (1987, 1989). Her investigation, which included previously overlooked, delicate, mat- or net-like foraminiferal taxa that are a major element of these encrusting assemblages, was based on box core samples from the central $\left(30^{\circ} \mathrm{N}\right.$, $\left.157^{\circ} \mathrm{W}\right)$ and tropical $\left(5^{\circ} \mathrm{N}, 125^{\circ} \mathrm{W}\right)$ North Pacific. Other deep-sea, hard substratum communities that have been studied systematically at the same spatial scales (centimeters-millimeters) as the nodules include sponge stalks (Beaulieu, 2001), indurated sediment around hydrothermal vents (Jonasson et al., 1995; Jonasson and Schröder-Adams, 1996), dropstones (Heron-Allen and Earland, 1932; Gooday, unpublished data), large foraminiferal tests (Gooday and Haynes, 1983), experimental substrates on seamounts (Bertram and Cowen, 1994) and sunken woods (Turner, 1973). At a larger spatial scale, Tilot (2006a, b) has examined the megafaunal assemblages of the nodule ecosystem in the tropical North Pacific Ocean.

Several major research programs in the Pacific and Indian Oceans have investigated the potential impacts of nodule mining. These include: DISCOL (Disturbance and Recolonization Experiment in a Manganese Nodule Area of the Deep South Pacific Ocean) (Borowski and Thiel, 1998; Thiel et al., 2001), BIEs (Benthic Impact 
Experiments) (Sharma et al., 2000; Sharma et al., 2001; Radziejewska, 2002), JET (Japan Deep-sea Impact Experiment) (Fukushima 1995) and INDEX (Indian Deepsea Environment Experiment) (Raghukumar et al., 2001). However, these studies did not specifically consider the impact of nodule mining on the nodule-dwelling fauna.

The objective of the present study was to improve knowledge of pristine nodule faunas in order to facilitate environmentally sustainable management of mining activities. The spatial distribution of the nodule fauna was analyzed at two scales: a regional scale that includes the east $\left(14^{\circ} \mathrm{N}, 130^{\circ} \mathrm{W}\right)$ and the west $\left(9^{\circ} \mathrm{N}, 150^{\circ} \mathrm{W}\right)$ zones and a local scale within which different nodule facies (A, B, C and west) were recognizable. Water depth was similar in the two zones (varying from 4900 to 5050 m). Four properties of the nodule substratum that could influence faunal distribution were also examined: nodule size, geochemical composition, morphology and surface texture. We analyzed the distribution of species among zones and facies, and nodule groupings using faunal characteristics in order to determine the most influential factors on faunal spatial distribution. Finally, species assemblages were investigated as a potential factor structuring faunal distributions on nodules.

The present study extends previous work by Mullineaux $(1987,1989)$ in several key respects. First, we carried out a sampling method comparison, comparing results from nodules obtained with a USNEL box corer with those from nodules scooped up by the Nautile submersible. Secondly, the large number of nodules sampled at locations 
that differed from those studied by Mullineaux permitted extensive characterization, quantification and distribution analysis of nodule fauna. The spatial distribution of the nodule fauna at the scale of the nodule itself is considered in a separate paper (Veillette et al., in press).

\section{Materials and methods}

\subsection{Sampling sites}

The NODINAUT cruise (RV l'Atalante; May $18^{\text {th }}-$ June $27^{\text {th }} 2004$ ) explored and sampled two geographical zones located in the French mining claim in the tropical Pacific: the east zone $\left(14^{\circ} \mathrm{N}, 130^{\circ} \mathrm{W}\right)$ and the west zone $\left(9^{\circ} \mathrm{N}, 150^{\circ} \mathrm{W}\right)$ (Fig. 1$)$. Both zones are located in the Clarion-Clipperton Fracture Zone at depths varying from 4900 to 5050m. The east zone is located to the north of Mullineaux’s (1987) equatorial Pacific site. It was previously visited by the NIXONAUT cruise (November $18^{\text {th }}-$ December $22^{\text {nd }} 1988$ ) (Cochonat et al., 1992). Three different nodule facies were observed in the east zone (A, B and C) where they cover hundreds of square kilometers. The facies were differentiated according to their general shape, size, surface morphology of the nodules and the relation between the nodule and its environment (degree of burial in the sediment, presence of volcanic material) (Saguez, 1985; Morel and Le Suavé, 1986). Facies A nodules were small spheres (less than $4 \mathrm{~cm}$ diameter) with smooth surfaces and lay at the surface of the sediments 
on slight slopes. Facies C nodules were the largest (average of $11 \mathrm{~cm}$ diameter) but their sizes varied considerably (from 2 to $15 \mathrm{~cm}$ diameter). They appeared as half buried spheres in the sediments. Knobs and protrusions characterized their smoothtextured upper region and their sides were rough. Facies B nodules were ovoid, medium in size (average length $5 \mathrm{~cm}$ ), most of their surface texture was rough and they were slightly buried in the sediments. An undescribed facies that characterizes the west zone is referred to as the "west facies". These nodules were generally ovoid but occurred in different shapes. They were small to medium in size (from 2 to $9 \mathrm{~cm}$ in length), their surface texture was rough and they were slightly buried in the sediments. Even though our visual classification, commonly used by geologists, appears to be subjective, differences in the geochemical composition of the nodules from different facies support this approach (Tilot, 1992, 1993; Hoffert and Saget, 2004).

Primary productivity in this region is estimated to be moderate compared to the high equatorial productivity (DuCastel, 1985; Skornyakova and Murdmaa, 1992; Knoop et al., 1998). We developed estimates of surface chlorophyll, mixed layer depth, primary productivity and production export for $5^{\circ}$ boxes around the east and west zones, using SeaWiFs ocean color data and numerical modeling. Surface chlorophyll was slightly higher in the east zone (Fig. 2 and Table 1), as was primary productivity (Table 1). The greatest difference between the two zones was for export production (Table 1). While the sedimentation rate in the Clarion-Clipperton Fracture Zone 
appears to be moderate (Hoffert, pers. comm.), the east zone benefits from a greater flux of particulate organic carbon to the bottom, likely as a result of longitudinal advection of organic matter. The east zone lies beneath the North Equatorial Current and the west zone beneath the North Equatorial Counter Current (DuCastel, 1985; Smith and Demopoulos, 2003).

Near-bottom currents observed during the NODINAUT cruise (short term ADCPWH300 measurements at ten meters above the bottom) were very weak and were of the same order in the two zones $\left(3.5-4 \mathrm{~cm} \mathrm{~s}^{-1}\right)$. Their direction was toward east/south-east in the east zone and east/north-east in the west zone meaning that nodule faunas do not always experience unidirectional currents. There were some very slight speed and direction variations due to semi-diurnal tidal oscillations. Previous long-term data (Pujol, 1988; Mauviel, 1990) indicated the existence of inertial oscillations ( $2-3$ days) and longer term oscillations (around $2-3$ months) of higher amplitude. According to these data, the current direction encountered during the NODINAUT cruise was always associated with higher current speeds. We assume, therefore, that the NODINAUT cruise took place during a period when current speeds were somewhat higher than normal.

Bottom relief can influence current speed and direction (Morgan et al., 1999). We attempted to estimate currents at the scale of the nodules at several $\mathrm{cm}$ above the bottom with a modified weathercock but results are too preliminary to be significant. 
Measured bottom water temperature in both zones was around $1^{\circ} \mathrm{C}$. Seawater chemical properties measured at the nodule scale $(\mathrm{pH}$, salinity, dissolved oxygen, alkalinity, dissolved organic carbon (DOC) and nutrients) were also similar in the two zones.

\subsection{Sampling methods}

Nodules were sampled using either a USNEL box corer (sampled area of 50 X $50 \mathrm{~cm}$ ) or the manipulator of the Nautile submersible (Table 2 and 3). A top-view photo of each USNEL box core was taken before eight randomly chosen nodules were removed from the sediment and washed carefully with seawater. The sampled nodules were stored in 4\% formaldehyde and transferred to $70 \%$ alcohol after several days. They were all carefully packed for transportation in jars of different sizes. Plastic packing was placed in the jars to immobilize the nodules. During all manipulations, nodules were never allowed to dry and were handled with the greatest care possible because of their high friability.

The two different sampling methods (USNEL box corer versus Nautile submersible) were compared in order to test the effect of sampling method on our results and on nodule integrity and fauna. We were particularly interested in whether: 1) the sampling method influenced the size of the nodules collected; 2) one sampling method was more destructive than the other, damaging the most fragile living forms 
and decreasing species richness. The nodule surface above the sediment line was used as an indicator of nodule size.

\subsection{Nodule substratum}

Four characteristics of the nodule substratum were considered in relation to faunal distribution: nodule size, geochemical composition, morphology and texture. The influence of nodule size on the attached fauna was investigated by testing regressions of species richness, species density and percent faunal cover in relation to the nodule surface above the sediment line. For the geochemical composition analysis, the metallic composition of a nodule cross section from each facies was determined. We were specifically interested in possible relationships between the fauna and the geochemical composition of the outer nodule layer. Nodule morphology and texture are described elsewhere (Veillette et al., in press).

\subsection{Nodule surface area determination}

Nodule surface area was calculated in order to compare zones and facies. Since nodule surfaces below the sediment line are rarely colonized, only the area above the sediment line was considered. This exposed surface area was determined differently for each facies since the constituent nodules exhibited different morphologies. The entire surface of facies A nodules could be colonized since they were situated on the 
sediment surface. For these nodules, the surface area available for colonization was estimated using the sphere surface formula $\left(4 \pi r^{2}\right)$. Facies B and west nodules were mostly ovoid and buried in the sediment. Their surface area was determined using IP Lab Spectrum $(\subset)$ image analysis software, assuming that top-view photos provided a good representation of nodule surface area above the sediment line. Facies $\mathrm{C}$ nodules appeared as spheres half buried in the sediment. When the vertical or near vertical sides of the nodules extended more than $30 \mathrm{~mm}$ above the sediment before flattening to form the upper region, the surface area was separated into top and side. In order to control for the irregular shape of most nodules, eight measures of the height of the sides were taken at every $45^{\circ}$ around the nodule circumference. When the sides of facies $\mathrm{C}$ nodules were $30 \mathrm{~mm}$ or less in height, nodule surface area was determined using the same methodology as for facies B and west. For nodules greater than 30 mm in side heights, side surface area was calculated using the surface formula for an open cylinder (height x circumference). All measurements and surface determination with IP Lab Spectrum $(\mathcal{C}$ were made in triplicate.

\subsection{Faunal identification and quantification}

The fauna associated with 235 nodules (greater than $18 \mathrm{~mm}$ in length), collected either by a USNEL box corer or by the Nautile from four different nodule facies, was described quantitatively (Table 4). The total nodule surface area examined was 0.715 $\mathrm{m}^{2}$. Identification of living organisms on nodule surfaces was done using a binocular 
dissecting microscope. High power light microscopy and scanning electron microscopy were also used to examine smaller forms or particular structures and to determine if unknown forms were protozoans, metazoans or inorganic forms. The tests of most foraminifera (protozoans) were partially broken in order to determine if protoplasm was present and therefore whether the organism was alive or dead.

Foraminiferal species that were considered to be alive at the time of collection (based on the presence of intact protoplasm) were quantified. However, some foraminifera, for example, komokiacean-like forms in which the test interior is dominated by stercomata, rarely contained visible protoplasm. In these cases, unbroken tests were regarded as being live when collected. Despite all precautions taken during handling of the nodules, some very fragile structures may have been destroyed or lost prior to identification. Thus, faunal identifications in this study could be biased towards more robust forms firmly attached to nodule surfaces.

Faunal mats and domes were quantified by their percent cover (Mullineaux, 1987), whereas upright structures were quantified by their presence/absence. Presence/absence data were used to calculate species richness, defined as "the number of species present, without any regard for the exact area or number of individuals examined” (Hurlbert, 1971). The surface area covered by upright structures is negligible and thus, the percent cover includes all forms covering the nodule surface. In order to simplify the faunal cover analysis, every encrusting 
species was assumed to represent a circle or a rectangle. The dimensions of the organisms were then measured under a binocular microscope equipped with an eyepiece scale. For species forming anastomosing networks, percent cover within the limits of the structure was estimated. Density (number of individuals per unit area) was not used in this study since the vast majority of the living forms were foraminifera that were best quantified in terms of percent cover (Mullineaux, 1987).

We recognised two foraminiferal feeding types. Type I included species in which the test contained cytoplasm and lacked obvious accumulations of stercomata (faecal pellets). In feeding type II , which included komokiaceans such as Chrondrodapis, the test contains accumulations of stercomata and the cytoplasm is very sparse.

\subsection{Statistical analyses}

The quantitative comparison of faunal species richness, species density and percent cover between zones included all nodules, since the sample sizes of both zones were relatively similar $\left(n_{\text {east }}=104, n_{\text {west }}=131\right.$; Table 4$)$. The non-parametric Mann-Whitney test was used to test for differences between the two zones because the two main assumptions for the $t$-test (homogeneity of variances and normal distributions) were never met. All nodules were included in the inter-facies comparisons but unbalanced sample size $\left(n_{A}=15, n_{B}=50, n_{C}=39, n_{\text {west }}=131\right.$; Table 4$)$ was controlled for. Spatial bias could not be controlled for because of the variation in the number of sampling 
sites between facies (Table 4). The non-parametric Kruskal-Wallis test was used to test for differences between the four facies since the two main assumptions for ANOVA (homogeneity of variances and normal distributions) were never met. When the result of the Kruskal-Wallis test was significant, the Tukey a posteriori test, was used to verify which distributions differed from the others. Nodules were classified into three size categories according to Hoffert and Saget (2004): small $<5 \mathrm{~cm}$ in length, medium 5-10 cm in length, and large $>10 \mathrm{~cm}$ in length. Nodules in the same size category (Table 5) were compared quantitatively in order to explore faunal differences caused by factors other than nodule surface area. The two zones could be compared but only three facies could be compared together since nodule sizes of facies A and C do not overlap (small: A, B and west, medium: B, C and west). When nodules with similar dimensions were compared, the sample size used was the smallest for the groups being compared in order to assure equal variances. Nodules were randomly chosen from the two other groups. When nodules with similar dimensions were compared between the two zones, the $t$-test was used if the assumptions were met. Otherwise, the non-parametric Mann-Whitney test was used. When nodules of the same size from different facies were compared, ANOVA was used if the assumptions were respected. The non-parametric Kruskal-Wallis test was used when they were not. When the ANOVA result was significant, the Tukey $a$ posteriori test was used to verify which distributions differed from the others. All analyses were made at $\alpha=0.05$. 
The distribution of species among facies was analyzed to determine whether the nodules harboured specific species. Most of the species confined to a single facies were found in facies $\mathrm{C}$ (Table 6), where the nodules were biggest. We tested the hypothesis that species were evenly distributed on every facies. Redundancy analyses (RDA) were performed on abundance as well as on presence/absence data from 60 randomly-chosen nodules (15 nodules/facies). All data were Hellinger-transformed since this transformation is appropriate for the analysis of community composition data (Legendre and Gallagher, 2001).

Nodules were grouped using faunal characteristics in order to test the influence of facies on the nodule fauna. Different grouping methods were explored using either abundance or presence/absence data from 60 randomly-chosen nodules (15 nodules/facies, Table 4): Jaccard index (presence/absence data), PCA, K-means Euclidean ordination (abundance data) and Ward agglomerative grouping (abundance data).

Kendall's coefficient of concordance $(W)$ was used to identify species associations with Hellinger-transformed abundance data (Legendre, 2005) from 60 randomlychosen nodules (15 nodules/facies). The objective of this analysis was to test if species were independent of one another, or if they formed significant faunal assemblages. 


\section{Results}

\subsection{Sampling methods}

For facies B and C nodules, the two sampling methods yielded different size

distributions (Table 5). The results of the analyses showed that the nodules sampled with the submersible Nautile were statistically bigger for both facies (Fig. 3). The dominant species on the nodules sampled by the USNEL box corer and the Nautile were slightly different, but in general all sampled nodules yielded similar assemblages of delicate organisms (Table 8A and 8B). The sampling method did not seem to influence species richness for facies B and C since the species accumulation curves of the two sampling methods overlapped (Fig. 4). Facies west nodules collected with the Nautile had lower species richness than those collected with the USNEL box corer. The number of nodules observed appeared to be sufficient since all accumulation curves tended towards an asymptote, where the number of new species observed no longer increased with increasing sample size (Fig. 4). However, some of these trends [Facies A, B (PL), C (USNEL)] could also be artefacts due to the small number of observed nodules.

\subsection{Nodule faunal composition}


We identified a total of 73 protozoan and 17 metazoan species associated with nodule surfaces (see “Catalogue of nodule fauna”) (Fig. 5 and Table 6). Eleven protozoan and 8 metazoan species were identified to species or genus level, the remainder were indeterminate, i.e. they could not be assigned to any described species or genera. The protozoans were all foraminifera, with the exception of two probable xenophyophores. They were all attached directly to the nodule surface except for five species, which were incorporated into agglutinated mats.

Around $70 \%$ (62 out of 90) of the species observed were considered to be living when collected. However, the proportion was substantially higher for protozoans (78\%) than for metazoans (29\%). Only these 62 live species (57 protozoans and 5 metazoans) were included in the species richness analysis. Sixty percent of the protozoan species represented feeding type I based on the presence of stercomata-free protoplasm. The remainder (37\%) are considered to be feeding type II based on the accumulation of stercomata within the test (Gooday et al., 1997). All metazoan species (except “mud tube”) were classified as suspension feeders.

Percent cover was used to quantify the extent of colonization at the time of sampling. Out of the 62 live species, 41 protozoans (mostly mats, domes and tunnels) and one metazoan (the ascidian Cnemidocarpa sp.) were quantified by percent cover. Fauna covered up to $18 \%$ of the exposed nodule surface, with a mean of about $3 \%$. 


\subsection{Species richness and density}

Species richness per nodule was higher in the east zone than in the west zone (Fig. 6A) even when nodules of the same size were compared (Table 7). Moreover, at the facies scale, facies $\mathrm{C}$ followed by facies B hosted more species than facies A or west as confirmed by the Tukey test (Fig. 7A). Also, facies B nodules yielded a more diverse assemblage than facies A or west nodules when only small nodules were considered (Table 7). On the other hand, facies $\mathrm{C}$ nodules were more species rich than facies B or west nodules when only medium nodules were included in the analysis (Table 7).

Species density (number of species per $\mathrm{mm}^{2}$ ) was not significantly higher in the east zone than in the west zone (Fig. 6B). However, when only small nodules were considered, species density was higher in the east than in the west zone (Table 7). At the facies level, facies B had the highest species density, while facies A and west were not different, and facies $\mathrm{C}$ had the lowest species density according to the Tukey test (Fig. 7B). These rankings still hold when only small nodules were compared but in this case, facies $\mathrm{C}$ was not included (Table 7). For medium nodules, there was no significant difference in species density between facies B and C, or between facies C and facies west. However, facies B had a higher species density than facies west (Table 7). 


\subsection{Percent cover}

Percent faunal cover was significantly higher in the east zone than in the west zone even when the same nodule sizes were compared (Fig. 6C). At the facies scale, facies B nodules were more heavily encrusted with fauna than facies C, followed by facies A and west according to the Tukey test (Fig. 7C). These trends remained true for small nodules only, although in this case, facies $\mathrm{C}$ was not included (Table 7). However, there were no differences in percent cover between facies B, C and west for medium nodules (Table 7).

\subsection{Nodule size}

Facies C nodules were larger than facies A, B or west nodules when nodules obtained using both sampling methods were pooled together (Fig. 3). There was no significant difference in nodule surface area between facies A, B and west. We examined the relationship between nodule size and species richness, species density and percent cover. It might be expected that the number of species would increase with nodule surface area. Figure 7A shows that the regression between the number of species and the exposed nodule surface is significant when all nodules are considered $(\mathrm{P}<0.0001)$, at both the regional (east, $\mathrm{P}<0.0001$; west, $\mathrm{P}<0.0001$ ) and the facies scales (facies $\mathrm{B}$, $\mathrm{P}=0.0310$; facies $\mathrm{C}, \mathrm{P}<0.0001)$, except for facies $\mathrm{A}(\mathrm{P}=0.1882)$. These regressions exhibit positive slopes, as expected. The regressions between species density and 
exposed nodule surface are significant as well (all, $\mathrm{P}<0.0001$; east, $\mathrm{P}<0.0001$; west, $\mathrm{P}=0.0011$; facies $\mathrm{B}, \mathrm{P}<0.0001$; facies $\mathrm{C}, \mathrm{P}<0.0001$ ), again except for facies $\mathrm{A}$ ( $\mathrm{P}=0.8656)$ (Fig. 8B). Nevertheless, the slopes of these regressions are negative, meaning that the number of species per unit surface area decreased with nodule size. Furthermore, there is no relation between faunal cover and exposed nodule surface when all nodules are included $(\mathrm{P}=0.5219)$ (Fig. 8C). However, east zone $(\mathrm{P}<0.0001)$ as well as facies $\mathrm{B}(\mathrm{P}=0.0161)$ and $\mathrm{C}(\mathrm{P}<0.0001)$ nodules present significant regressions with negative slopes.

\subsection{Species distributions between facies}

Tables $8 \mathrm{~A}$ and $8 \mathrm{~B}$ show, respectively, the relative abundance of the top ten species in both zones (Table 8A) and among the four facies studied (Table 8B). Seven species were abundant in both zones and six species were abundant in every facies. Two foraminiferal species were observed only on facies A nodules, one foraminiferal species was only found on facies B, one unattached foraminiferan and ten metazoan species were noted only on facies $\mathrm{C}$ nodules and two unattached forms of foraminifera only occurred on facies west (Table 6).

For all facies, the redundancy analyses show similar patterns with abundance and presence/absence data (Fig. 9). Species 1 and 36 seem to be strongly associated with facies west. Species 22, 23, 45, 19, 28 and 46 were found mostly in the east zone. 
Although species 28 and 46 were present in every facies, their abundance was much greater on facies $\mathrm{C}$ nodules. However, these trends, although significant $(\mathrm{p}=0.0005$ and $p=0.0001$ ), explain only a very small portion of the variance of the distribution of species among facies $\left(\mathrm{R}^{2}=0.054\right.$ and $\left.\mathrm{R}^{2}=0.063\right)$.

\subsection{Nodule grouping and species assemblages}

Nodule grouping using the Jaccard index method yielded three groups of seven, two and 49 nodules. Nodules were at most 75\% similar. The PCA, K-means Euclidean ordination and the Ward agglomerative grouping method used abundance data and yielded similar results. For the PCA, K-means Euclidean ordination, six groups composed of eight, five, four, two, ten and 26 nodules respectively were formed. The Ward agglomerative grouping method also formed six groups, containing in this case nine, two, 20 and three groups, each of eight nodules. The nodules composing these groups were almost the same ones, irrespective of the method used.

Table 9C shows that two significant groups of associated species exist: one that includes two species and the other including six species. The remaining 34 species (out of 42) are independently distributed.

\section{Discussion}




\subsection{Sampling methods}

There was a bias toward the sampling of larger nodules with the Nautile submersible. However, the nodule size differences were too slight to explain the observed faunal differences and nodules collected using both methods were therefore pooled. In future studies, human bias in the collection of nodules with the submersible could easily be minimized by using a sampling frame with the same area as that sampled by the box corer $(50 \mathrm{X} 50 \mathrm{~cm})$. This frame could be laid out on the sediment surface and nodules randomly collected from within. Any remaining variation between the two sampling methods could then be attributed to differences in the degree to which they damaged the nodule fauna.

The smaller seafloor area sampled could explain the lower species richness of the facies west nodules collected with Nautile submersible compared to those collected with the USNEL box corer. Together, the ten USNEL box cores sampled a larger surface area of the west zone than the samples from the dive PL1605-13. To test this hypothesis, the fauna on six nodules from one USNEL box core was compared to six random nodules from PL1605-13. Species richness was not significantly different between the two sets of nodules $\left(t_{0.05(2), 10}=2.228, \mathrm{p}=0.2545\right)$. Hence, the smaller seafloor area sampled rather than the sampling method may explain the different species accumulation curves obtained for this facies. This conclusion could apply to facies A nodules as well since only 15 nodules from one submersible dive were 
available for analyses. The results obtained from facies A nodules might also reflect the fact that the nodules were collected from a relatively small area ('location effect') rather than being a facies effect.

\subsection{Comparisons with previous studies}

Approximately 21 protozoan species out of 73 recorded in this study resembled taxa listed by Mullineaux (1987) from her central and equatorial Pacific sites and the metazoan groups were similar to those observed by her as well. None of the protozoan and metazoan species colonizing nodule surfaces has been observed among soft sediment communities at either the east (Nozawa et al., 2006) or west (Ohkawara, 2006) zones. Dugolinsky (1976) and Mullineaux (1987) likewise reported a lack of overlap between sediment and nodule-dwelling faunas at their Pacific study sites. Data on the abundance and diversity of foraminifera living in the sediment between the nodules at the east and west zones are difficult to compare with our observations since the assemblages were quantified in terms of numbers of individuals and fragments (Nozawa et al., 2006). These sediment assemblages consisted mainly of monothalamous soft-shelled taxa and fragments of komokiaceans and tubular species.

Species richness of the nodule fauna analyzed in this study was dominated by foraminiferans (92.4\%), as also observed by Mullineaux (1987) and Dugolinsky 
(1976). Taxa colonizing some other hard substrata, such as the interior of Bathysiphon rusticus tubes (Gooday and Haynes, 1983) and experimental substrata on seamounts (Bertram and Cowen, 1994) are also dominated by foraminifera. This protozoan group may play a more significant ecological role in deep-sea benthic communities, particularly in terms of carbon cycling, than the metazoan macrofaunal taxa on which deep-sea ecological studies have often focussed (Gooday,2003;

Nomaki et al., 2005). It has been suggested that sediment-dwelling foraminifera reach their highest diversity on abyssal plains (Buzas and Gibson, 1969; Gooday et al., 1998). Where present, the nodule assemblages will further enhance these diversity levels. The sponge stalks studied by Beaulieu (2001), on the other hand, were predominantly colonized by metazoans. In our material, metazoans were represented mainly by the remnants of dead organisms, for example, empty worm tubes. Indeed, these structures were more common on exposed nodule surfaces than dead foraminiferan tests. This probably reflects the fact that the metazoan structures were more robust than those built by protozoans.

Although presence/absence data included more species than percent cover data, the latter provides a better indicator of the magnitude of faunal colonization. On this basis, the nodules that we examined exhibited a species richness similar to that of nodules studied by Mullineaux (1987). However, since the species accumulation curves tended towards an asymptote but did not reach it (Fig. 4), these must be regarded as minimum values. Species richness depends upon the sampling effort and 
inter-site comparisons are meaningful only if faunal characterization is sufficient (Etter and Mullineaux, 2001). Species richness of metazoan-dominated sponge stalk communities (total number of species observed=144; Beaulieu, 2001) is higher than that of nodule fauna. On the other hand, while nodule species density for the east (0.9 species $\mathrm{cm}^{-2}$ ) and the west $\left(0.7\right.$ species $\mathrm{cm}^{-2}$ ) zones was slightly lower than for sponge stalks (1.1 species $\mathrm{cm}^{-2}$; Beaulieu, 2001), species density on facies B nodules (1.4 species $\mathrm{cm}^{-2}$ ) was higher. Percent faunal cover on nodules (average of 3\%) was lower but of the same order of magnitude as that reported by Mullineaux (1987) (average of 10\%). Sponge stalks were almost entirely covered by fauna (Beaulieu, 2001), and faunal coverage on experimental substrata from Cross Seamount (central North Pacific, $410 \mathrm{~m}$ depth) reached $37 \%$ on basalt surfaces and $13 \%$ and $20 \%$ on ferromanganese-oxide and $\mathrm{CaCO}_{3}$ substrata, respectively (Bertram and Cowen, 1994).

Two foraminiferal feeding types (I and II), characterised respectively by the presence and absence of stercomata accumulations, were distinguished. Most species were low-lying domes and mats, which we suspect feed mainly on the organic material, microorganisms and clay-sized sediment particles present on nodule surfaces (Burnett and Nealson, 1981). In contrast, the sponge stalk fauna described by Beaulieu (2001) included a variety of feeding types (scavengers, mobile predators, suspension and deposit feeders), most of them metazoans. Deposit feeders usually dominate deep-sea sediment communities (Hessler and Jumars, 1974; Etter and Mullineaux, 2001) and 
abyssal species are usually generalists (Dayton and Hessler, 1972). However, structures extending from the sediment into higher current flow above the benthic boundary layer, such as nodules, sponge stalks or rocks, can provide a hard substratum for suspension feeders (Beaulieu, 2001; Etter and Mullineaux, 2001). All of our nodule-dwelling metazoans were considered to be suspension feeders. In the case of nodule mining, it is predicted that suspension and deposit feeders living adjacent to mined areas will be most heavily influenced by sediment resuspension and deposition (Jumars, 1981).

\subsection{Environmental influences on nodule faunas}

Current speeds were uniformly low at both study sites and the chemical properties of bottom-water masses were also similar. These factors are therefore unlikely to have influenced the nodule faunas, except in the sense that some current motion is required for renewing water surrounding nodules, replenishing particulate food and removing waste material (Thistle, 2003). The flux of particulate organic carbon to deep-sea benthic ecosystems often overrides other environmental factors and exerts a controlling influence on many aspects of deep-sea benthic ecology (Gooday, 2002) and diversity (Levin et al., 2001). This probably applies to hard-substrate faunas as it does to sediment-dwelling communities. 
An east-west gradient of decreasing surface productivity is known to occur in the equatorial Pacific (Smith and Demopoulos, 2003). However, notable differences in productivity along this gradient are most apparent at scales of many tens of degrees of longitude (Knoop et al. 1998, Christian et al. 2002), rather than at the scale of the $20^{\circ}$ separation of our east and west zones. Furthermore, the Clarion-Clipperton Fracture Zone is located at the northern margin of the equatorial zone of high productivity where nutrients upwell (Murray et al., 1994) and is therefore more food-limited than areas closer to the equator. Nonetheless, our modeling results showed that the eastern zone sampled in this study experiences a higher carbon flux to the deep ocean than our western zone, as a result of higher productivity combined with longitudinal advection of organic matter. This regional difference in organic matter flux may explain the higher species richness and percent faunal cover in the east zone, although, as observed by Mullineaux (1987), it apparently does not have much effect on faunal composition at the species level.

Mullineaux (1987) recorded 24 of her 56 nodule-dwelling foraminiferal species at both of her sites in the central and equatorial North Pacific. More than half (13) of the monothalamous species that she recognized occurred at both sites, despite the fact that the equatorial Pacific is characterized by higher surface productivity that the central North Pacific. This suggests that some nodule-dwelling species have wide distributions, at least at the regional scale, that are independent of organic matter supply. 


\subsection{Influence of nodule characteristics on faunas}

Nodule size can influence species richness, species density and percent faunal cover. Our data show that species richness increases with nodule size. The non-significance of the regressions between nodule size and these parameters in the case of facies A could be explained by the smaller sample size $(n=15)$, their collection from a limited spatial area during the same submersible dive, and the fact that the nodules were small (Table 5). The negative slope of the regressions between species density and exposed nodule surface implies that the number of species observed on a nodule reaches a maximum value at a threshhold nodule surface area. This suggests that species richness is not limited by the space on the nodule surface available for colonization. The relationship of percent cover and nodule surface area is negative for the east zone and facies B and C. Furthermore, there is no link between species richness and percent faunal cover.

Scanning electron microprobe geochemical analysis of the nodule outer surfaces (Étoubleau et al., 2000) produced maps of relative concentrations of metals. Some trends were common to all facies: a patchy presence of highly concentrated iron, a uniform layer of highly concentrated cobalt and patches of highly concentrated calcium. There were also geochemical differences between facies. Facies A and C nodules showed silica correlated with calcium and manganese spots just beneath the 
surface. The outer metallic composition of facies west nodules was different from that of the other nodule facies, exhibiting higher manganese and nickel concentrations and some sparse spots of copper. No clear relationship was found between fauna and the geochemical composition of the outer nodule surface.

The RDA analyses of species distribution among facies based on abundance and presence/absence yielded very similar results (Fig. 9). The analyses suggest that facies type significantly influences the composition of nodule fauna, although it is probably not the main regulating factor. In deep-sea sedimentary environments, small-scale heterogeneity has been invoked to explain high local species diversity in soft-bottom communities (Grassle and Maciolek, 1992; Snelgrove and Smith, 2002). The higher species richness on facies $\mathrm{C}$ and $\mathrm{B}$ nodules could be due to the presence of morphological irregularities, such as knobs, protrusions and depressions, that create habitat heterogeneity and different ecological niches for the encrusting fauna. Similarly, cluster analyses of the fauna colonizing sponge stalks suggested that substratum complexity may have an influence on communities (Beaulieu, 2001). In contrast, the lower species richness on spherical facies A nodules and on the regularly-shaped facies west nodules may reflect the relative lack of surface irregularities. Nodule surface texture, either rough or smooth, could also contribute to the structuring of the faunal spatial distribution (Mullineaux and Butman, 1990). This may be related to, among other factors, the responses of larvae and other dispersive propagules to surface texture. See Veillette et al. (in press) for a more detailed 
discussion on the roles of nodule surface characteristics and microhabitats in structuring faunal communities.

\subsection{Nodule grouping and species assemblages}

Nodule groupings were examined to ascertain why certain nodules grouped together based on species-level analyses. Nodules that did not join with the largest group obtained by the Jaccard index method were mostly facies A and west nodules. This suggests that the faunal composition of facies B and C nodules was similar and distinct from that of facies A or west. Also, nodules coming from the same box core or dive tended to cluster more closely, indicating that their faunas were similar. Nodules grouping with the PCA, K-means Euclidean ordination and the Ward agglomerative grouping method did not correspond to any facies type, indicating again that facies type is not the main factor influencing the nodule fauna. Moreover, sponge stalks act as isolated island habitats for encrusting organisms (Beaulieu, 2001) whereas nodules are often a dominant habitat, which offer a much greater area for colonization at larger spatial scales.

Thirty-four species out of 42 were independently distributed (Table 9), suggesting that species interactions play only a minor role in explaining the distribution of the fauna on the nodules. The species assemblages that we recognize did not include metazoans since only their presence or absence was recorded, not their abundance. 
Moreover, the vast majority were dead when collected. Metazoans were mostly found on facies $\mathrm{C}$ which is composed of the largest nodules and this is probably related to the higher flow necessary for suspension feeding.

\section{Conclusions}

The higher species richness and percent faunal cover found on nodules of the east zone can be attributed, at least in part, to greater food availability. The complex, knobby micro-relief of facies B and C nodules probably creates microhabitat heterogeneity that could have contributed to the greater species richness of the east zone. Nodule size also exerted a significant influence on the nodule fauna; in most cases, species richness increased with the area of exposed nodule surface while species density decreased. The analysis of the distribution of species among facies explained only a very small portion of the variance and species assemblages only played a minor role in the spatial distribution of nodule fauna. During mining, there will be avoidable and unavoidable impacts. One unavoidable impact is the loss of the nodule as a habitat and of the special fauna inhabiting its surface and crevices. A much fuller understanding of the biodiversity and biogeography of nodule-dwelling species is required before we can determine the threat to any identified member of the nodule fauna or before we can begin monitoring the impact of nodule mining, if and when it becomes a reality. 


\section{Acknowledgements}

This research would not have been possible without the help of the NODINAUT scientific party. We extend great thanks to everyone in the Laboratoire Environnement Profond of Ifremer in Brest and to Ifremer for its financial support. We also thank the Atalante ship crew and Nautile pilots as well as Joëlle Galéron, chief scientist of the cruise. We thank the metazoan taxonomic specialists: P. Hayward (bryozoans), R. von Cosel (mollusks), F. Monniot (ascidians) and D. Gaspard (brachiopods). We also thank P. Legendre and his students for their great help with the statistical analyses. A.J. Gooday participated in this study as part of the project "Biodiversity, species ranges, and gene flow in the abyssal Pacific nodule province: Predicting and managing the impacts of deep seabed mining” supported by the Kaplan Foundation and International Seabed Authority. This research partially fulfilled requirements for a Masters degree in environmental sciences by the senior author at Université du Québec à Montréal.

\section{References}

Beaulieu, S.E., 2001. Life on glass houses: sponge stalk communities in the deep sea. Marine Biology 138, 803-817.

Bertram, M.A. and Cowen, J.P., 1994. Testate rhizopod growth and mineral deposition on experimental substrates from Cross Seamount. Deep-Sea Research I 41, 575-601.

Bignot, G. and Lamboy, M., 1980. Les foraminifères épibiontes à test calcaire hyalin des encroûtements polymétalliques de la marge continentale au nord-ouest de la péninsule ibérique. Revue de Micropaléontologie 23, 3-15. 
Borowski, C. and Thiel, H., 1998. Deep-sea macrofaunal impacts of a large-scale physical disturbance experiment in the Southeast Pacific. Deep-Sea Research II 45, 55-81.

Burnett, B.R. and Nealson, K.H., 1981. Organic films and microorganisms associated with manganese nodules. Deep-Sea Research 28A, 637-645.

Buzas, M.A. and Gibson, T.G., 1969. Species diversity: Benthonic Foraminifera in Western North Atlantic. Science 163, 72-75.

Christian, J.R., Verschell, M.A., Murtugudde, R., Busalacchi, A.J. and McClain, C.R., 2002. Biogeochemical modelling of the tropical Pacific Ocean. I. Seasonal and interannual variability. Deep-Sea Research II 49, 509-543.

Cochonat, P., Le Suavé, R., Charles, C., Greger, B., Hoffert, M., Lenoble, J.-P., Meunier, J. and Pautot, G., 1992. First in situ studies of nodule distribution and geotechnical measurements of associated deep-sea clay (Northeastern Pacific Ocean). Marine Geology 103, 373-380.

Dayton, P.K. and Hessler, R.R., 1972. Role of biological disturbance in maintaining diversity in the deep sea. Deep-Sea Research 19, 199-208.

Du Castel, V., 1985. Établissement d'une carte géologique au 1/20000 d'un domaine océanique profond dans une zone riche en nodules polymétalliques du Pacifique Nord (zone Clarion-Clipperton). Thèse de doctorat, Brest, unpublished.

Dudley, W.C., 1976. Cementation and iron concentration in foraminifera on manganese nodules. Journal of Foraminiferal Research 6, 202-207.

Dudley, W.C., 1978. Biogenic influence on the composition and structure of marine manganese nodules. Colloque International du C.N.R.S. sur la Genèse des Nodules de Manganèse.

Dudley, W.C. and Margolis, S.V., 1974. Iron and trace element concentration in marine manganese nodules by benthic agglutinated foraminifera. Geological Society of America, Abstracts with Programs 6, 716.

Dugolinsky, B.K., 1976. Chemistry and morphology of deep-sea manganese nodules and the significance of associated encrusting protozoans on nodule growth. Ph.D. thesis, unpublished. 
Dugolinsky, B.K., Margolis, S.V. and Dudley, W.C., 1977. Biogenic influence on growth of manganese nodules. Journal of Sedimentary Petrology 47, 428-445.

Ehrlich, H.L., 1972. The role of microbes in manganese nodule genesis and degradation. Conference on Ferromanganese Deposits on the Ocean Floor. pp. 63-70.

Étoubleau, J., Bohn, M., Fouquet, Y., Cambon, P. et R., LeSuavé, 2000. Apport des techniques par rayons $\mathrm{X}$ à la caractérisation des encroûtements cobaltifères océaniques. Journal de Physique IV France 10, 363-374.

Etter, R.J. and Mullineaux, L.S., 2001. Deep-sea Communities. In: Bertness, M.D., Gaines, S.D. and Hay, M.E. (Eds.), Marine Community Ecology. Sinauer Associates, Inc., Sunderland, Massachusetts, pp. 367-393.

Fukushima, T., 1995. Overview of Japan deep-sea impact experiment 1/4 JET. In: Proceedings of the First ISOPE-Ocean Mining Symposium, Tsukuba, Japan, pp. 4753.

Glover, A.G. and Smith, C.R., 2003. The deep-sea floor ecosystem: current status and prospects of anthropogenic change by the year 2025. Environmental Conservation 30, 219-241.

Gooday, A.J. 2002. Biological responses to seasonally varying fluxes of organic matter to the ocean floor: a review. Journal of Oceanography 58, 305-332.

Gooday, A.J. 2003. Benthic foraminifera (Protista) as tools in deep-water palaeoceanography: a review of environmental influences on faunal characteristics. Advances in Marine Biology 46, 1-90.

Gooday, A.J. and Haynes, J.R., 1983. Abyssal foraminifers, including two new genera, encrusting the interior of Bathysiphon rusticus tubes. Deep-Sea Research 30, 591-614.

Gooday, A.J., Bett, B.J., Shires, R., Lambshead, P.J.D. 1998. Deep-sea benthic foraminiferal diversity in the NE Atlantic and NW Arabian sea: a synthesis. Deep-Sea Research II 45, 165-201.

Gooday, A.J., Shires, R. and Jones, A.R., 1997. Large, deep-sea agglutinated foraminifera: two differing kinds of organization and their possible ecological significance. Journal of Foraminiferal Research 27, 278-291.

Graham, J.W. and Cooper, S.C., 1959. Biological origin of manganese-rich deposits on the sea floor. Nature 183, 1050-1051. 
Grassle, J.F. and Maciolek, N.J., 1992. Deep-sea species richness: regional and local diversity estimates from quantative bottom samples. The American Naturalist 139, 313-341.

Greenslate, J., Hessler, H.L. and Thiel, H., 1974. Manganese nodules are alive and well on the sea floor. 10th Annual Conference Proceedings, Marine Technology Society. pp. 171-181.

Heron-Allen, E. and Earland, A., 1932. Foraminifera Part I. The ice-free area of the Falkland Islands and adjacent seas. Discovery Reports 4, 291-460.

Hessler, R.R. and Jumars, P.A., 1974. Abyssal community analysis from replicate box cores in the central North Pacific. Deep-Sea Research 21, 185-209.

Hoffert, M. and Saget, P., 2004. Manuel d'identification des "faciès nodules" pour la zone de plongées Nixo-45. Ifremer, Brest, unpublished.

Honjo, S., 1996. Fluxes of particles to the interior of the open oceans. In: Ittekkot, V., Schäfer, P., Honjo, S. and Depetris, P.J. (Eds.), Particle flux in the ocean, SCOPE Report 57. John Wiley and Sons, New York, pp. 91-154.

Hurlbert, S.H., 1971. The nonconcept of species diversity: a critique and alternative parameters. Ecology 52, 577-586.

Jonasson, K.E. and Schröder-Adams, C.J., 1996. Encrusting agglutinated foraminifera on indurated sediment at a hydrothermal venting area on the Juan de Fuca Ridge, northeast Pacific Ocean. Journal of Foraminiferal Research 26, 137-149.

Jonasson, K.E., Schröder-Adams, C.J. and Patterson, R.T., 1995. Benthic foraminiferal distribution at Middle Valley, Juan de Fuca Ridge, a northeast Pacific hydrothermal venting site. Marine Micropaleontology 25, 151-167.

Jumars, P.A., 1981. Limits in predicting and detecting benthic community responses to manganese nodule mining. Marine Mining 3, 213-229.

Knoop, P.A., Owen, R.W. and Morgan, C.L., 1998. Regional variability in ferromanganese nodule composition: northeastern tropical Pacific Ocean. Marine Geology 147 1-12.

Legendre, P., 2005. Species Associations: The Kendall Coefficient of Concordance Revisited. Journal of Agricultural, Biological, and Environmental Statistics 10, 226245. 
Legendre, P. and Gallagher, E.D., 2001. Ecologically meaningful transformations for ordination of species data. Oecologia 129, 271-280.

Levin, L.A., Etter, R. J., Rex, M.A., Gooday, A.J., Smith, C. R. S., Pineda, J., Stuart, C.T., Hessler, R.R. and Pawson, D. 2001. Environmental influences on regional deepsea species diversity. Annual Review of Ecology and Systematics 32, 51-93.

Mauviel, F., 1990. Campagne de mesures océanométéorologiques. Mouillage courantométrique de subsurface (NIXO 46). Résultats statistiques. Toulon. GEMONOD.

Maybury, C., 1996. Crevice foraminifera from abyssal South East Pacific manganese nodules. In: Moguilevsky, A. and Whatley, R. (Eds.), Microfossils and Oceanic Environments. Aberystwyth-Press, University of Wales, pp. 281-295.

Morel, Y. and Le Suavé, R., 1986. Variabilité de l'environnement morphologique et sédimentaire dans un secteur intra plaque du Pacifique Nord (zone ClarionClipperton). Bulletin de la Société Géologique de France 8, 361-372.

Morgan, C.L., Odunton, N.A. and Jones, A.T., 1999. Synthesis of environmental impacts of deep seabed mining. Marine Georesources and Geotechnology 17, 307356.

Mullineaux, L.S., 1987. Organisms living on manganese nodules and crusts: distribution and abundance at three North Pacific sites. Deep-Sea Research 34, 165184.

Mullineaux, L.S., 1989. Vertical distributions of the epifauna on manganese nodules: Implications for settlement and feeding. Limnology and Oceanography 34, 12471262.

Mullineaux, L.S. and Butman, C.A., 1990. Recruitment of encrusting benthic invertebrates in boundary-layer flows: A deep-water experiment on Cross Seamount. Limnology and Oceanography 35 (2), 409-423.

Murray, J.W., Barber, R.T., Roman, M.R., Bacon, M.P. and Feely, R.A., 1994. Physical and biological controls on carbon cycling in the equatorial Pacific. Science 266, 58-65.

Nomaki, H., Heinz, P., Nakatsuka, T., Shimanaga, M. and Kitazato, H. 2005. Species-specific ingestion of organic carbon by deep-sea benthic foraminifera and 
meiobenthos: in situ tracer experiments. Limnology and Oceanography 50 (1), 134146.

Nozawa, F., Kitazato, H., Tsuchiya, M. and Gooday, A.J., 2006. 'Live’ benthic foraminifera at an abyssal site in the equatorial Pacific nodule province: Abundance, diversity and taxonomic composition. Deep-Sea Research I 53, 1406-1422.

Ohkawara, N., 2006. Deep-sea benthic foraminiferal fauna in the central Equatorial Pacific. Unpublished undergraduate thesis, Hirosaki University, Japan, 26 pp, figs 116 , tables 1-5, pls 1-25.

Pujol, S., 1988. Étude de la courantologie dans la zone "nodules" du Pacifique Est et des oscillations d'inertie. Rapport de stage "Maîtrise et Techniques de la mer", unpublished.

Radziejewska, T., 2002. Responses of deep-sea meiobenthic communities to sediment disturbance simulating effects of polymetallic nodule mining. International Review of Hydrobiology 87 (4), 457-477.

Raghukumar, C., Bharathi, P.A.L., Ansari, Z.A., Nair, S., Ingole, B., Sheelu, G., Mohandass, C., Nath, B.N. and Rodrigues, N., 2001. Bacterial standing stock, meiofauna and sediment-nutrient characteristics: indicators of benthic disturbance in the Central Indian Basin. Deep-Sea Research II 48, 3381-3399.

Riemann, F., 1983. Biological aspects of deep-sea manganese nodule formation. Oceanologica Acta 6, 303-311.

Riemann, F., 1985. Iron and manganese in Pacific deep-sea rhizopods and relationships to manganese nodule formation. Internationale Revue der gesamten Hydrobiologie 70, 165-172.

Saguez, G., 1985. Étude de la morphologie, de la structure interne et de la lithologie des nodules polymétalliques de la zone Clarion-Clipperton: relations avec l'environnement. Ph.D. Thesis, Brest, unpublished.

Sharma, R., Nagender, N.B., Parthiban, G. and Jai, S.S., 2001. Sediment redistribution during simulated benthic disturbance and its implication on deep seabed mining. Deep-Sea Research II 48, 3363-3380.

Sharma, R., Nagendernath, B., Valsangkar, A.B., Parthiban, G., Sivakolundu, K.M. and Walker, G., 2000. Benthic disturbance and impact experiments in the Central Indian Ocean Basin. Marine Georesources and Geotechnology 18, 209-221. 
Skornyakova, N.S. and Murdmaa, I.O., 1992. Local variations in distribution and composition of ferromanganese nodules in the Clarion-Clipperton Nodule Province. Marine Geology 103, 381-405.

Smith, C.R. and Demopoulos, A.W.J., 2003. The Deep Pacific Ocean Floor. In: Tyler, P.A. (Ed.), Ecosystems of the World 28. Elsevier, Amsterdam, pp. 179-218.

Snelgrove, P.V.R. and Smith, C., 2002. A riot of species in an environmental calm: The paradox of the species-rich deep-sea floor. Oceanography and Marine Biology 40, 311-342.

Thiel, H., 1978. The faunal environment of manganese nodules and aspects of deep sea time scales. In: Krumbein, W.E. (Ed.), Proceedings of the Third International Symposium on Environmental Biogeochemistry. Ann Arbor Science Publishers inc., pp. 887-896.

Thiel, H., 2003. Anthropogenic impacts on the deep sea. In: Tyler, P.A. (Ed.), Ecosystems of the World 28. Elsevier, Amsterdam, pp. 427-472.

Thiel, H., Schriever, G., Ahnert, A., Bluhm, H., Borowski, C. and Vopel, K., 2001. The large-scale environmental impact experiment DISCOL-reflection and foresight. Deep-Sea Research II 48, 3869-3882.

Thiel, H., Schriever, G., Bussau, C. and Borowski, C., 1993. Manganese nodule crevice fauna. Deep-Sea Research I 40, 419-423.

Thistle, D., 2003. The Deep-Sea Floor: an Overview. In: Tyler, P.A. (Ed.), Ecosystems of the Deep Oceans 28. Elsevier, Amsterdam, pp. 5-37.

Tilot, V., 1992. La structure des assemblages mégabenthiques d'une province à nodules polymétalliques de l'océan Pacifique tropical Est. Thèse de doctorat, Brest, unpublished.

Tilot, V., 1993. La structure des assemblages mégabenthiques d'une province à nodules polymétalliques de l'océan Pacifique tropical Est, 1993. Annales de l' Institut Océanographique, nouvelle série 69 (2), 344-346.

Tilot, V., 2006a. Biodiversity and distribution of the megafauna. Vol. 1. The polymetallic nodule ecosystem of the Eastern Equatorial Pacific Ocean. Intergovernmental Oceanographic Commission. Technical Series 69, Project UNESCO COI/Min Vlanderen, Belgium. 
Tilot, V., 2006b. Biodiversity and distribution of the megafauna. Vol. 2. Annotated photographic atlas of the echinoderms of the Clarion-Clipperton fracture zone. Intergovernmental Oceanographic Commission. Technical Series 69, Project UNESCO COI/Min Vlanderen, Belgium.

Turner, R.D., 1973. Wood-boring bivalves, opportunistic species in the deep sea. Science 180, 1377-1379.

Veillette, J., Juniper, S.K., Gooday, A.J. et Sarrazin, J., 2006. Influence of surface texture and microhabitat heterogeneity in structuring nodule faunal communities. Deep-Sea Research I. In press.

von Stackelberg, U., 1984. Significance of benthic organisms for the growth and movement of manganese nodules, Equatorial North Pacific. Geo-Marine Letters 4, 37-42.

Wendt, J., 1974. Encrusting organisms in deep-sea manganese nodules. International Association of Sedimentologists, Special Publications 1, 437-447. 


\section{Tables}

Table 1. Summary of surface ocean physical and biological properties for a $5^{\circ}$ box around the east and the west zones sampled during the study from a biogeochemical ocean model simulation (Christian et al., 2002). Mean (standard deviation) of monthly output from 1980-2003. The model was forced with NCEP weekly winds. Export is calculated at a depth of $\sim 1200 \mathrm{~m}$.

\begin{tabular}{|l|c|c|}
\hline & East zone & West zone \\
\hline Mixed layer depth $(\mathrm{m})$ & 58.8 & 65.5 \\
& $(20.6)$ & $(20.0)$ \\
\hline Surface chl $a\left(\mathrm{mg} \mathrm{m}^{-3}\right)$ & 0.194 & 0.160 \\
& $(0.087)$ & $(0.068)$ \\
\hline Primary production $\left(\mathrm{mmol} \mathrm{C} \mathrm{m}^{-2} \mathrm{~d}^{-1}\right)$ & 29.1 & 23.4 \\
\hline Export $\left(\mathrm{mmol} \mathrm{C} \mathrm{m}^{-2} \mathrm{~d}^{-1}\right)$ & 11.2 & 8.1 \\
\hline
\end{tabular}


Table 2. Nodule abundance and percent cover from USNEL box cores.

\begin{tabular}{|c|c|c|c|c|}
\hline USNEL & Depth (m) & Facies $^{1}$ & $\begin{array}{l}\text { Total number of } \\
\text { nodules }^{2}\end{array}$ & $\begin{array}{l}\text { Total nodule } \\
\text { percent cover }^{3}\end{array}$ \\
\hline \multicolumn{5}{|c|}{ East zone } \\
\hline KGS-1 & 5036 & $\mathrm{C}$ & Disturbed $^{4}$ & Disturbed \\
\hline KGS-3 & 5005 & C & Disturbed & Disturbed \\
\hline KGS-6 & 4974 & C & Disturbed & Disturbed \\
\hline KGS-7 & 4996 & $\mathrm{C}$ & Disturbed & Disturbed \\
\hline KGS-21 & 4911 & B & 91 & 35.3 \\
\hline KGS-22 & 4954 & B & 92 & 48.7 \\
\hline KGS-23 & 4935 & B & 169 & 55.6 \\
\hline KGS-24 & 4904 & B & 114 & 52.8 \\
\hline KGS-25 & 4930 & B & 97 & 52.7 \\
\hline \multicolumn{5}{|c|}{ West zone } \\
\hline KGS-28 & 5050 & West & 53 & 26.1 \\
\hline KGS-29 & 5050 & West & 22 & 22.6 \\
\hline KGS-30 & 5051 & West & 97 & 45 \\
\hline KGS-31 & 5055 & West & 78 & 8.2 \\
\hline KGS-32 & 5048 & West & 116 & 18.2 \\
\hline KGS-33 & 5043 & West & 19 & 8.9 \\
\hline KGS-36 & 5048 & West & 64 & 24.3 \\
\hline KGS-37 & 5054 & West & 16 & 4.5 \\
\hline KGS-38 & 5051 & West & 63 & 24.7 \\
\hline KGS-39 & 5051 & West & 88 & 37.9 \\
\hline KGS-40 & 5059 & West & Disturbed & Disturbed \\
\hline KGS-41 & 5050 & West & Disturbed & Disturbed \\
\hline
\end{tabular}

${ }^{1}$ Facies A nodules were not sampled with USNEL box core.

2. Determined by direct counting in top-view pictures (average of triplicates).

${ }^{3 .}$ Determined with image analysis software IP Lab Spectrum( $\odot$ (average of triplicates).

4. "Disturbed" means that the content of the box core was well mixed and that the number of nodules and the nodule percent cover were impossible to estimate. 
Table 3. Sampling strategy used for nodules collected with the manipulator of the submersible Nautile.

\begin{tabular}{|l|l|l|l|}
\hline Dive & Depth (m) & Facies & Sampling strategy \\
\hline East zone & 4955 & A & $\begin{array}{l}\text { All nodules were placed in a small box. } \\
\text { 15 nodules were present. }\end{array}$ \\
\hline PL1593-01 & 4971 & C & $\begin{array}{l}\text { Nodules were placed with difficulty in } \\
\text { small boxes. }\end{array}$ \\
\hline PL1598-06 & 4983 & C & $\begin{array}{l}\text { Nodules were placed directly in the } \\
\text { basket. }\end{array}$ \\
\hline PL1602-10 & 4987 & B & $\begin{array}{l}\text { Nodules were placed in small boxes in } \\
\text { groups of 4. }\end{array}$ \\
\hline PL1603-11 & 5040 & West & $\begin{array}{l}\text { Nodules were placed in small boxes } \\
\text { full of sediments. The first 15 nodules } \\
\text { encountered were taken (length >18 } \\
\text { mm). }\end{array}$ \\
\hline PL1605-13 & \multicolumn{2}{|l}{} \\
\hline
\end{tabular}


Table 4. Number and type of nodules used for the different analyses included in this study. Number of sampling sites are indicated between parentheses.

\begin{tabular}{|c|c|c|c|c|c|c|c|}
\hline \multirow[t]{2}{*}{ Facies } & \multicolumn{4}{|c|}{$\begin{array}{l}\text { Faunal species richness, species density and } \\
\text { percent cover quantitative analyses }\end{array}$} & \multicolumn{3}{|c|}{$\begin{array}{l}\text { RDA analysis, nodule grouping and } \\
\text { species assemblage analyses }\end{array}$} \\
\hline & USNEL & $\begin{array}{l}\text { Nautile } \\
\text { submersible }\end{array}$ & $\begin{array}{l}\text { Total } \\
\text { number } \\
\text { of } \\
\text { nodules }\end{array}$ & $\begin{array}{l}\text { Total } \\
\text { surface } \\
\text { area }\left(\mathrm{m}^{2}\right)\end{array}$ & USNEL & $\begin{array}{l}\text { Nautile } \\
\text { submersible }\end{array}$ & $\begin{array}{l}\text { Total } \\
\text { number } \\
\text { of } \\
\text { nodules }\end{array}$ \\
\hline \multicolumn{8}{|c|}{ East zone } \\
\hline A & 0 & $15(1)$ & 15 & 0.019 & 0 & $15(1)$ & 15 \\
\hline $\mathrm{B}$ & $40(5)$ & $10(1)$ & 50 & 0.074 & $10(4)$ & $5(1)$ & 15 \\
\hline $\mathrm{C}$ & $14(4)$ & $25(2)$ & 39 & 0.457 & $7(3)$ & $8(2)$ & 15 \\
\hline \multicolumn{3}{|l|}{ Total } & 104 & 0.550 & & & 45 \\
\hline \multicolumn{8}{|c|}{ West zone } \\
\hline West & $71(12)$ & $60(1)$ & 131 & 0.164 & $4(3)$ & $11(1)$ & 15 \\
\hline \multicolumn{3}{|l|}{ Total } & 235 & 0.715 & & & 60 \\
\hline
\end{tabular}


Table 5. Numbers of nodules observed in three size categories as described by Hoffert and Saget (2004).

\begin{tabular}{|l|l|l|l|l|l|}
\hline \multirow{2}{*}{$\begin{array}{l}\text { Sampling } \\
\text { method }\end{array}$} & Facies & Number of nodules & $\begin{array}{l}\text { Total number } \\
\text { of nodules }\end{array}$ \\
\cline { 3 - 5 } & & $\begin{array}{l}\text { Small }(<5 \mathrm{~cm} \\
\text { in length) }\end{array}$ & $\begin{array}{l}\text { Medium (5-10 } \\
\text { cm in length) }\end{array}$ & $\begin{array}{l}\text { Large (>10 cm } \\
\text { in length) }\end{array}$ & 0 \\
\hline Nautile & A & 15 & 0 & 0 & 15 \\
\hline Box core & B & 30 & 10 & 0 & 40 \\
\hline Nautile & B & 3 & 7 & 0 & 10 \\
\hline Box core & C & 3 & 9 & 2 & 14 \\
\hline Nautile & C & 0 & 5 & 20 & 25 \\
\hline Box core & West & 48 & 23 & 0 & 71 \\
\hline Nautile & West & 42 & 18 & 0 & 60 \\
\hline Total & & & & 235 \\
\hline
\end{tabular}


Table 6. List of species colonizing the four facies of the 235 nodules analyzed in this study.

\begin{tabular}{|c|c|c|c|c|c|c|c|c|}
\hline & Protozoan species $^{1}$ & $\mathrm{~A}^{2}$ & $\mathrm{~B}^{2}$ & $\mathrm{C}^{2}$ & West $^{2}$ & $\begin{array}{l}\text { Live/ } \\
\text { Dead }^{3}\end{array}$ & $\begin{array}{l}\text { Percent } \\
\text { cover }^{4}\end{array}$ & $\begin{array}{l}\text { Feeding } \\
\text { type }^{5}\end{array}$ \\
\hline & Domes and lumps & & & & & & & \\
\hline 1 & Pseudowebbinella sp. & 0 & $\mathrm{x}$ & $\mathrm{x}$ & $\mathrm{x}$ & Live & $x$ & I \\
\hline 2 & Hemispherammina-like, pale regular dome & $\mathrm{x}$ & $\mathrm{x}$ & $\mathrm{x}$ & $\mathrm{x}$ & Live & $\mathrm{x}$ & I \\
\hline 3 & Hemispherammina-like, pale granular dome & $\mathrm{x}$ & $\mathrm{x}$ & $\mathrm{x}$ & $\mathrm{x}$ & Live & $\mathrm{x}$ & I \\
\hline 4 & Hemisperammina-like, irregular shape & $\mathrm{x}$ & $\mathrm{x}$ & $\mathrm{x}$ & $\mathrm{x}$ & Live & $\mathrm{x}$ & I \\
\hline 5 & Tholosina sp. & 0 & $x$ & $x$ & 0 & Live & $x$ & $\mathrm{I}$ \\
\hline 6 & Tholosina-like & $x$ & $x$ & $x$ & 0 & Live & $x$ & I \\
\hline 7 & Trochammina-like & $x$ & $x$ & $x$ & $x$ & Live & & I \\
\hline 8 & Placopsilina-like & $x$ & $x$ & $x$ & $x$ & Live & $x$ & I \\
\hline 9 & Komoki, mud-ball type & $x$ & $x$ & $x$ & $x$ & Live & $x$ & II \\
\hline 10 & Whitish sparkling dome & $x$ & 0 & 0 & $x$ & Live & $x$ & I \\
\hline 11 & Whitish flattened dome & $x$ & 0 & 0 & $x$ & Live & $x$ & I \\
\hline 12 & White granular patches & $x$ & $x$ & $x$ & $x$ & Live & & $\mathrm{I}$ \\
\hline 13 & Ammocibicides-like & $x$ & $x$ & $x$ & $x$ & Live & $x$ & I \\
\hline 14 & Fine agglutinated particles beige soft dome & $x$ & $x$ & $x$ & $x$ & Live & $x$ & I \\
\hline 15 & Brown granular shiny dome & 0 & $x$ & $x$ & $x$ & Live & $x$ & II \\
\hline 16 & Black granular dome & 0 & $x$ & $x$ & $x$ & Dead & & II \\
\hline 17 & Black soft dome & $\mathrm{x}$ & $\mathrm{x}$ & $\mathrm{x}$ & $\mathrm{x}$ & Live & $x$ & II \\
\hline \multirow[t]{2}{*}{18} & Orange dome & $\mathrm{x}$ & $\mathrm{x}$ & $x$ & $\mathrm{x}$ & Live & $x$ & I \\
\hline & Mats & & & & & & & \\
\hline 19 & Chondrodapis hessleri & $x$ & $x$ & $x$ & $x$ & Live & $x$ & II \\
\hline 20 & Chondrodapis integra & $x$ & $x$ & $x$ & $x$ & Live & $x$ & II \\
\hline 21 & $\begin{array}{l}\text { Area covered with komokiacean-like chambers } \\
\text { linked with fine tubes }\end{array}$ & $x$ & $x$ & $x$ & $x$ & Live & $x$ & II \\
\hline 22 & Grey granular mat & $x$ & $x$ & $x$ & $x$ & Live & $x$ & II \\
\hline 23 & $\begin{array}{l}\text { Very thin muddy patches with komokiacean- } \\
\text { like chambers }\end{array}$ & $x$ & $x$ & $x$ & $x$ & Live & $x$ & II \\
\hline 24 & Telammina & $x$ & $x$ & $x$ & $x$ & Live & & I \\
\hline 25 & Tumidotubus & $x$ & $x$ & $x$ & $x$ & Live & $x$ & I \\
\hline 26 & $\begin{array}{l}\text { Xenophyophorea-like, without agglutinated } \\
\text { particles }\end{array}$ & $x$ & $x$ & $x$ & $\mathrm{x}$ & Dead & & II \\
\hline 27 & Xenophyophorea-like, fan-shaped agglutinated & 0 & $\mathrm{x}$ & $\mathrm{x}$ & $\mathrm{x}$ & Dead & & II \\
\hline 28 & "White crust" & $\mathrm{x}$ & $\mathrm{x}$ & $x$ & $x$ & Live & $x$ & I \\
\hline 29 & “Beige filamentous mat” & 0 & $\mathrm{x}$ & $x$ & $\mathrm{x}$ & Live & $x$ & $?$ \\
\hline
\end{tabular}




\begin{tabular}{|c|c|c|c|c|c|c|c|c|}
\hline 30 & "Dark chambered mat" & 0 & $x$ & $x$ & 0 & Live & $x$ & II \\
\hline 31 & Thin grey mat & $x$ & $\mathrm{x}$ & $x$ & $x$ & Live & $\mathrm{x}$ & 1 \\
\hline 32 & Thin organic mat with dark grey stercomata & $x$ & $x$ & $x$ & $x$ & Live & $x$ & II \\
\hline 33 & Beige thick mat with red interior & $x$ & 0 & 0 & 0 & Live & $x$ & I \\
\hline 34 & Beige thick and smooth mat, interior brown & $x$ & $x$ & $x$ & $x$ & Live & $x$ & I \\
\hline 35 & Mat of blue flattened chambers & $x$ & $x$ & $x$ & $x$ & Live & $x$ & $?$ \\
\hline 36 & White mat with lumps & $x$ & $x$ & $x$ & $x$ & Live & $x$ & I \\
\hline 37 & White crusty mat with coarse particles & 0 & 0 & $x$ & $x$ & Live & $x$ & I \\
\hline 38 & Orange, rigid agglutinated wall in crevice & 0 & $x$ & $x$ & $x$ & Dead & & I \\
\hline \multirow[t]{2}{*}{39} & Mat of very coarse sediment agglutinated & 0 & $\mathrm{x}$ & $x$ & $x$ & Dead & & I \\
\hline & Tunnels & & & & & & & \\
\hline 40 & “Thin anastomosing tunnels” & $x$ & $\mathrm{x}$ & $x$ & $x$ & Live & & I \\
\hline 41 & "Cemented tunnels" & $\mathrm{x}$ & $x$ & $x$ & $x$ & Live & $x$ & $\mathrm{I}$ \\
\hline 42 & Reticulated dark tunnels & $x$ & $\mathrm{x}$ & $x$ & $x$ & Live & $x$ & I \\
\hline 43 & $\begin{array}{l}\text { Network of beige tunnels; horizontal tree with } \\
\text { upright branches }\end{array}$ & 0 & $x$ & $x$ & $x$ & Live & $x$ & II \\
\hline 44 & Crystal star and tunnels & 0 & $x$ & $x$ & $x$ & Live & $x$ & I \\
\hline 45 & Spider network of grey tunnels & $x$ & $x$ & $x$ & $x$ & Live & $x$ & I \\
\hline 46 & White soft tunnels & $x$ & $x$ & $x$ & $x$ & Live & $x$ & $\mathrm{I}$ \\
\hline \multirow[t]{2}{*}{47} & Network of empty beige tunnels & 0 & $x$ & $x$ & $x$ & Dead & & I \\
\hline & Connected chambers & & & & & & & \\
\hline 48 & Chain of orange/brown chambers & $x$ & $x$ & $x$ & $x$ & Dead & & 1 \\
\hline 49 & "Flattened chambers" & $x$ & $\mathrm{x}$ & $x$ & $x$ & Live & $x$ & II \\
\hline 50 & Chain of empty grey and rounded chambers & 0 & $\mathrm{x}$ & $x$ & $x$ & Dead & & I \\
\hline 51 & Hormosina sp. & $x$ & $\mathrm{x}$ & $x$ & $x$ & Live & $x$ & I \\
\hline \multirow[t]{2}{*}{52} & Brown chain of spheres rigidly agglutinated & 0 & 0 & $x$ & 0 & Dead & & I \\
\hline & Upright tubes & & & & & & & \\
\hline 53 & $\begin{array}{l}\text { Network of branched tubes either lying down } \\
\text { on the nodule surface or standing }\end{array}$ & $x$ & $x$ & $x$ & $x$ & Live & & II \\
\hline 54 & Psammotodendron indivisum- like & 0 & $x$ & $x$ & $x$ & Live & & I \\
\hline 55 & $\begin{array}{|lll|}\begin{array}{l}\text { Komokiacean-like chambers on delicate } \\
\text { filaments }\end{array} & & \\
\end{array}$ & $x$ & $\mathrm{x}$ & $x$ & $x$ & Live & & II \\
\hline 56 & Upright beige tubules with constrictions & 0 & $x$ & $x$ & $x$ & Live & & II \\
\hline 57 & Upright beige structures & 0 & $x$ & 0 & 0 & Live & & I \\
\hline 58 & Tube upright with komokiacean-like chambers & $x$ & $\mathrm{x}$ & $x$ & 0 & Live & & II \\
\hline 59 & Branched upright tubules & $x$ & $x$ & $x$ & $x$ & Live & & II \\
\hline 60 & Upright tree & 0 & $x$ & $x$ & $x$ & Live & & II \\
\hline
\end{tabular}




\begin{tabular}{|c|c|c|c|c|c|c|c|c|}
\hline 61 & Upright filament & $x$ & $x$ & $\mathrm{x}$ & $x$ & Live & & II \\
\hline 62 & Upright filament, branched dichotomously & $x$ & $x$ & $\mathrm{x}$ & $x$ & Live & & II \\
\hline 63 & Upright beige tubule, two origins & $x$ & 0 & 0 & 0 & Live & & II \\
\hline 64 & Branching stercomata-filled tube & $x$ & $x$ & $\mathrm{x}$ & $x$ & Live & & II \\
\hline \multirow[t]{2}{*}{65} & Anastomosing Rhizammina-like & $x$ & $x$ & $x$ & $x$ & Live & $x$ & II \\
\hline & Recumbent tubes & & & & & & & \\
\hline 66 & Saccorhiza ramosa-like & 0 & $x$ & $x$ & $x$ & Dead & & $\mathrm{I}$ \\
\hline 67 & Tolypammina sp. & $x$ & $\mathrm{x}$ & $x$ & $x$ & Dead & & $\mathrm{I}$ \\
\hline \multirow[t]{2}{*}{68} & Horizontal organic tube full of stercomata & 0 & 0 & $x$ & $x$ & Live & $x$ & II \\
\hline & Unattached forms & & & & & & & \\
\hline 69 & Ammodiscus sp. & 0 & 0 & 0 & $x$ & Dead & & I \\
\hline 70 & Orange snail & 0 & 0 & 0 & $x$ & Dead & & I \\
\hline 71 & Biloculina sp. & 0 & $x$ & $x$ & $x$ & Dead & & I \\
\hline 72 & Quinqueloculina-like & 0 & $\mathrm{x}$ & $\mathrm{x}$ & 0 & Dead & & I \\
\hline \multirow[t]{3}{*}{73} & Thurammina-like & 0 & 0 & $x$ & 0 & Dead & & 1 \\
\hline & Metazoan species & & & & & & & \\
\hline & Sponges & & & & & & & \\
\hline M1 & Taxon 1: Porcupine & $x$ & $\mathrm{x}$ & $x$ & $x$ & Dead & & $\mathrm{S}$ \\
\hline M2 & Taxon 2: Sponge stalk with spikes & 0 & 0 & $\mathrm{x}$ & 0 & Dead & & $\mathrm{S}$ \\
\hline \multirow[t]{2}{*}{ M3 } & Taxon 3: White rigid stalk & 0 & 0 & $x$ & 0 & Dead & & S \\
\hline & Scyphozoans & & & & & & & \\
\hline M4 & Stephanoscyphus sp. & 0 & $x$ & $x$ & $x$ & Dead & & $S$ \\
\hline \multirow[t]{2}{*}{ M5 } & Taxon 1: Elongated scyphozoan & 0 & 0 & $x$ & 0 & Dead & & $\mathrm{S}$ \\
\hline & Mollusc & & & & & & & \\
\hline \multirow[t]{2}{*}{ M6 } & Bentharca asperula & 0 & $x$ & $x$ & 0 & Live & & $\mathrm{S}$ \\
\hline & Polychaetes & & & & & & & \\
\hline M7 & Taxon 1: Spiral & 0 & $x$ & $x$ & 0 & Dead & & $\mathrm{S}$ \\
\hline M8 & Taxon 2: Smooth tube & 0 & $x$ & $x$ & $x$ & Dead & & $\mathrm{S}$ \\
\hline M9 & Taxon 3: Tube with spikes & 0 & 0 & $x$ & 0 & Dead & & $\mathrm{S}$ \\
\hline \multirow[t]{2}{*}{ M10 } & Taxon 4: Mud tube & 0 & 0 & $\mathrm{x}$ & 0 & Dead & & $?$ \\
\hline & Bryozoans & & & & & & & \\
\hline M11 & Camptoplites sp. & 0 & $x$ & $x$ & 0 & Dead & & $\mathrm{S}$ \\
\hline M12 & Bugula sp. & 0 & 0 & $x$ & 0 & Dead & & $\mathrm{S}$ \\
\hline \multirow[t]{2}{*}{ M13 } & Cyclostomate & 0 & 0 & $x$ & 0 & Dead & & $\mathrm{S}$ \\
\hline & Brachiopods & & & & & & & \\
\hline M14 & Pelagodiscus atlanticus & 0 & 0 & $x$ & 0 & Live & & $\mathrm{S}$ \\
\hline
\end{tabular}




\begin{tabular}{|l|c|l|l|l|l|l|l|l|}
\hline M15 & Gwynia aff. capsula & 0 & $\mathrm{X}$ & $\mathrm{x}$ & 0 & Live & & $\mathrm{S}$ \\
\hline & Ascidian & & & & & & & \\
\hline M16 & Cnemidocarpa sp. & 0 & 0 & $\mathrm{x}$ & 0 & Live & $\mathrm{x}$ & $\mathrm{S}$ \\
\hline & Platyhelminthe, Turbellaria & & & & & & & \\
\hline M17 & Fecampia abyssicola & 0 & 0 & $\mathrm{x}$ & 0 & Live & & S \\
\hline
\end{tabular}

${ }^{1 .}$ Species in quotes have the same name as those described in Mullineaux (1987).

2. Presence (x) or absence $(0)$ of the species on nodules.

${ }^{3 .}$ Intact protoplasm was used to identify live specimens, and the "dead" designation was used when only remnant specimens were present on nodule surface.

4. Percent cover identifies species included in the percent cover study.

5. Feeding type I and II for Foraminifera correspond respectively to species without and with stercomata accumulations in their cytoplasm (Gooday et al., 1997), and from morphology and literature descriptions for metazoans (Mullineaux, 1987). 
Table 7. Results of the statistical tests comparing mean species richness, species density and percent cover for nodules of the same size category at the regional and facies scale.

\begin{tabular}{|c|c|c|}
\hline \multicolumn{3}{|l|}{ Zone } \\
\hline & Small & Medium \\
\hline Species richness & $\begin{array}{l}t_{0.05(2), \infty}=\mathrm{Z}=1.96 \\
\mathrm{P}<0.0001 \\
\text { East }>\text { west }\end{array}$ & $\begin{array}{l}t_{0.05(2), 60}=2.000 \\
\mathrm{P}<0.0001 \\
\text { East }>\text { west }\end{array}$ \\
\hline Species density & $\begin{array}{l}t_{0.05(2), \infty}=\mathrm{Z}=1.96 \\
\mathrm{P}<0.0001 \\
\text { East }>\text { west }\end{array}$ & $\begin{array}{l}t_{0.05(2), \infty}=\mathrm{Z}=1.96 \\
\mathrm{P}=0.6024 \\
\text { No difference }\end{array}$ \\
\hline Percent cover & $\begin{array}{l}t_{0.05(2), \infty}=\mathrm{Z}=1.96 \\
\mathrm{P}<0.0001 \\
\text { East }>\text { west }\end{array}$ & $\begin{array}{l}t_{0.05(2), \infty}=\mathrm{Z}=1.96 \\
\mathrm{P}=0.0018 \\
\text { East }>\text { west }\end{array}$ \\
\hline \multicolumn{3}{|l|}{ Facies } \\
\hline Species richness & $\begin{array}{l}\mathrm{F}_{0.05(1),(2),(42)}=3.23 \\
\mathrm{P}<0.0001 \\
\mathrm{~B}>\mathrm{A} \text { and west }\end{array}$ & $\begin{array}{l}\mathrm{F}_{0.05(1),(2),(39)}=3.23 \\
\mathrm{P}<0.0001 \\
\mathrm{C}>\mathrm{B} \text { and west }\end{array}$ \\
\hline Species density & $\begin{array}{l}\chi \mathrm{PP}^{2}{ }_{0.05,2}=5.991 \\
\mathrm{P}=0.0005 \\
\mathrm{~B}>\mathrm{A} \text { and west }\end{array}$ & $\begin{array}{l}\mathrm{F}_{0.05(1),(2),(39)}=3.23 \\
\mathrm{P}=0.0109 \\
\mathrm{~B} \text { and } \mathrm{C}>\mathrm{C} \text { and west }\end{array}$ \\
\hline Percent cover & $\begin{array}{l}\chi \mathrm{PP}^{2}{ }_{0.05,2}=5.991 \\
\mathrm{P}<0.0001 \\
\mathrm{~B}>\mathrm{A} \text { and west }\end{array}$ & $\begin{array}{l}\chi \mathrm{PP}^{2}{ }_{0.05,2}=5.991 \\
\mathrm{P}=0.1650 \\
\text { No difference }\end{array}$ \\
\hline
\end{tabular}


Table 8A. Ten most abundant species (out of 42) ranked in terms of percent cover of total fauna for all nodules analyzed in both zones ( $n=104$ for the east zone; $n=131$ for the west zone). Grey shading indicates species abundant in both zones.

\begin{tabular}{|ll|ll|}
\hline East zone & \% & West zone & \\
\hline Species & 26.59 & 25ecies & Tumidotubus \\
\hline $\begin{array}{l}\text { 23) Very thin muddy patches } \\
\text { with komokiacean-like } \\
\text { chambers }\end{array}$ & 13.25 & $\begin{array}{l}\text { 23) Very thin muddy patches } \\
\text { with komokiacean-like } \\
\text { chambers }\end{array}$ & 14.10 \\
\hline $\begin{array}{l}\text { 45) Spider network of grey } \\
\text { tunnels }\end{array}$ & 9.45 & $\begin{array}{l}\text { 32) Thin organic mat with dark } \\
\text { grey stercomata }\end{array}$ & 10.41 \\
\hline 31) Thin grey mat & 6.72 & $\begin{array}{l}\text { 45) Spider network of grey } \\
\text { tunnels }\end{array}$ & 9.79 \\
\hline $\begin{array}{l}\text { 32) Thin organic mat with dark } \\
\text { grey stercomata }\end{array}$ & 6.40 & $\begin{array}{l}\text { 21) Area covered with } \\
\text { komokiacean-like chambers } \\
\text { linked with fine tubes }\end{array}$ & 4.99 \\
\hline $\begin{array}{l}\text { 25) Tumidotubus } \\
\text { 19) Chondrodapis hessleri }\end{array}$ & 5.76 & 49) “Flattened chambers” & 4.85 \\
\hline 49) “Flattened chambers" & 4.59 & 22) Grey granular mat & 3.97 \\
\hline 28) “White crust” & 4.11 & 29) “Beige filamentous mat” & 3.84 \\
\hline $\begin{array}{l}\text { 34) Beige thick and smooth mat, } \\
\text { interior brown }\end{array}$ & 3.19 & 9) Komoki, mud-ball type & 3.46 \\
\hline 22) Grey granular mat & 2.64 & 31) Thin grey mat & 3.34 \\
\hline
\end{tabular}


Table 8B. Ten most abundant species (out of 42) ranked in terms of percent cover of total fauna for all nodules analyzed in every facies (A, n= 15; B, $n=50 ; C, n=39$; west, $n=131$ ). Grey shading indicates species abundant in the four facies.

\begin{tabular}{|c|c|c|c|c|c|c|c|}
\hline \multicolumn{2}{|l|}{ Facies A } & \multicolumn{2}{|l|}{ Facies B } & \multicolumn{2}{|l|}{ Facies C } & \multicolumn{2}{|l|}{ Facies west } \\
\hline Species & $\%$ & Species & $\%$ & Species & $\%$ & Species & $\%$ \\
\hline $\begin{array}{l}\text { 23) Very thin muddy } \\
\text { patches with } \\
\text { komokiacean-like } \\
\text { chambers }\end{array}$ & 36.62 & $\begin{array}{l}\text { 23) Very thin muddy } \\
\text { patches with } \\
\text { komokiacean-like } \\
\text { chambers }\end{array}$ & 28.80 & $\begin{array}{l}\text { 23) Very thin muddy } \\
\text { patches with } \\
\text { komokiacean-like } \\
\text { chambers }\end{array}$ & 25.47 & 25) Tumidotubus & 16.10 \\
\hline 22) Grey granular mat & 7.74 & $\begin{array}{l}\text { 45) Spider network of } \\
\text { grey tunnels }\end{array}$ & 17.07 & $\begin{array}{l}\text { 45) Spider network of } \\
\text { grey tunnels }\end{array}$ & 12.08 & $\begin{array}{l}\text { 23) Very thin muddy } \\
\text { patches with } \\
\text { komokiacean-like } \\
\text { chambers }\end{array}$ & 14.10 \\
\hline $\begin{array}{l}\text { 45) Spider network of } \\
\text { grey tunnels }\end{array}$ & 7.55 & $\begin{array}{l}\text { 19) Chondrodapis } \\
\text { hessleri }\end{array}$ & 7.17 & 31) Thin grey mat & 10.41 & $\begin{array}{l}\text { 32) Thin organic mat } \\
\text { with dark grey } \\
\text { stercomata }\end{array}$ & 10.41 \\
\hline $\begin{array}{l}\text { 32) Thin organic mat } \\
\text { with dark grey } \\
\text { stercomata }\end{array}$ & 7.54 & 31) Thin grey mat & 6.99 & 25) Tumidotubus & 7.39 & $\begin{array}{l}\text { 45) Spider network of } \\
\text { grey tunnels }\end{array}$ & 9.79 \\
\hline $\begin{array}{l}\text { 49) "Flattened } \\
\text { chambers" }\end{array}$ & 7.18 & $\begin{array}{l}\text { 32) Thin organic mat } \\
\text { with dark grey } \\
\text { stercomata }\end{array}$ & 6.44 & $\begin{array}{l}\text { 32) Thin organic mat } \\
\text { with dark grey } \\
\text { stercomata }\end{array}$ & 6.79 & $\begin{array}{l}\text { 21) Area covered with } \\
\text { komokiacean-like } \\
\text { chambers linked with } \\
\text { fine tubes }\end{array}$ & 4.99 \\
\hline 31) Thin grey mat & 6.89 & 22) Grey granular mat & 5.86 & $\begin{array}{l}\text { 19) Chondrodapis } \\
\text { hessleri }\end{array}$ & 5.36 & $\begin{array}{l}\text { 49) "Flattened } \\
\text { chambers" }\end{array}$ & 4.85 \\
\hline 25) Tumidotubus & 5.74 & 25) Tumidotubus & 3.69 & $\begin{array}{l}\text { 49) "Flattened } \\
\text { chambers" }\end{array}$ & 4.91 & 22) Grey granular mat & 3.97 \\
\hline $\begin{array}{l}\text { 42) Reticulated dark } \\
\text { tunnels }\end{array}$ & 4.39 & $\begin{array}{l}\text { 49) "Flattened } \\
\text { chambers" }\end{array}$ & 3.42 & 28) “White crust” & 4.82 & $\begin{array}{l}\text { 29) “Beige } \\
\text { filamentous mat" }\end{array}$ & 3.84 \\
\hline $\begin{array}{l}\text { 34) Beige thick and } \\
\text { smooth mat, interior } \\
\text { brown }\end{array}$ & 3.62 & $\begin{array}{l}\text { 34) Beige thick and } \\
\text { smooth mat, interior } \\
\text { brown }\end{array}$ & 3.25 & $\begin{array}{l}\text { 34) Beige thick and } \\
\text { smooth mat, interior } \\
\text { brown }\end{array}$ & 3.15 & $\begin{array}{l}\text { 9) Komoki, mud-ball } \\
\text { type }\end{array}$ & 3.46 \\
\hline $\begin{array}{l}\text { 19) Chondrodapis } \\
\text { hessleri }\end{array}$ & 2.71 & 28) “White crust” & 2.30 & 46) White soft tunnels & 2.90 & 31) Thin grey mat & 3.34 \\
\hline
\end{tabular}


Table 9. Results of the concordance tests among 42 nodule faunal species: A) overall test and B) a posteriori tests. To avoid spatial bias, 15 nodules were randomly selected from the four facies; five uncolonized nodules (one on facies $B$ and four on facies west) were excluded from the analysis. Hellinger-transformed abundance data for the remaining 55 nodules were used. $\mathrm{P}=$ permutational probability based upon 9999 random permutations. $\mathrm{P}_{\mathrm{H}}=$ Holm adjusted probability for multiple testing. C) Results based on the identification of associated species by K-means partitioning and Pearson correlation matrix. Only species significantly associated within each group by both methods are presented. (* $\alpha=0.05$.)

\begin{tabular}{|c|c|c|}
\hline \multicolumn{3}{|c|}{ A) Overall test of the $W$ statistic. $\mathrm{H}_{0}$ : The 42 species are not concordant with one another. } \\
\hline Kendall's $W=$ & 0.09164 & \\
\hline Friedman's chi-square $=$ & 207.84010 & $\mathrm{P}=0.0001 *$ \\
\hline \multicolumn{3}{|l|}{$H_{0}$ is rejected. Species are not all independent of one another. } \\
\hline \multicolumn{3}{|c|}{ B) A posteriori tests. $\mathrm{H}_{0}$ : This taxon is not concordant with the other 41 . } \\
\hline 1) Pseudowebbinella sp. & $\mathrm{P}=0.8427$ & $\mathrm{P}_{\mathrm{H}}=3.6864$ \\
\hline 2) Hemispherammina-like, pale regular dome & $\mathrm{P}=0.0003 *$ & $\mathrm{P}_{\mathrm{H}}=0.0117 *$ \\
\hline 3) Hemispherammina-like, pale granular dome & $\mathrm{P}=0.0472 *$ & $\mathrm{P}_{\mathrm{H}}=1.1064$ \\
\hline 4) Hemisperammina-like, irregular shape & $\mathrm{P}=0.0471 *$ & $\mathrm{P}_{\mathrm{H}}=1.1064$ \\
\hline 5) Tholosina sp. & $\mathrm{P}=0.0004 *$ & $\mathrm{P}_{\mathrm{H}}=0.0152 *$ \\
\hline 6) Tholosina-like & $\mathrm{P}=0.0354 *$ & $\mathrm{P}_{\mathrm{H}}=0.9204$ \\
\hline 8) Placopsilina-like & $\mathrm{P}=0.0004 *$ & $\mathrm{P}_{\mathrm{H}}=0.0152 *$ \\
\hline 9) Komoki, mud-ball type & $\mathrm{P}=0.0049 *$ & $\mathrm{P}_{\mathrm{H}}=0.1568$ \\
\hline 10) Whitish sparkling dome & $\mathrm{P}=0.4252$ & $\mathrm{P}_{\mathrm{H}}=3.6864$ \\
\hline 11) Whitish flattened dome & $\mathrm{P}=0.6639$ & $\mathrm{P}_{\mathrm{H}}=3.6864$ \\
\hline 13) Ammocibicides-like & $\mathrm{P}=0.0001 *$ & $\mathrm{P}_{\mathrm{H}}=0.0042 *$ \\
\hline 14) Fine agglutinated particles beige soft dome & $\mathrm{P}=0.0400 *$ & $\mathrm{P}_{\mathrm{H}}=1.0000$ \\
\hline 15) Brown granular shiny dome & $\mathrm{P}=0.1287$ & $\mathrm{P}_{\mathrm{H}}=2.3166$ \\
\hline 17) Black soft dome & $\mathrm{P}=0.1911$ & $\mathrm{P}_{\mathrm{H}}=2.8688$ \\
\hline 18) Orange dome & $\mathrm{P}=0.1169$ & $\mathrm{P}_{\mathrm{H}}=2.2211$ \\
\hline 19) Chondrodapis hessleri & $\mathrm{P}=0.0001 *$ & $\mathrm{P}_{\mathrm{H}}=0.0042 *$ \\
\hline 20) Chondrodapis integra & $\mathrm{P}=0.1793$ & $\mathrm{P}_{\mathrm{H}}=2.8688$ \\
\hline 21) Area covered with komokiacean-like chambers linked with fine tubes & $\mathrm{P}=0.0160 *$ & $\mathrm{P}_{\mathrm{H}}=0.4480$ \\
\hline 22) Grey granular mat & $\mathrm{P}=0.2136$ & $\mathrm{P}_{\mathrm{H}}=2.9904$ \\
\hline 23) Very thin muddy patches with komokiacean-like chambers & $\mathrm{P}=0.2562$ & $\mathrm{P}_{\mathrm{H}}=3.0744$ \\
\hline 25) Tumidotubus & $\mathrm{P}=0.0006 *$ & $\mathrm{P}_{\mathrm{H}}=0.0216 *$ \\
\hline 28) "White crust" & $\mathrm{P}=0.0002 *$ & $\mathrm{P}_{\mathrm{H}}=0.0080 *$ \\
\hline 29) "Beige filamentous mat" & $\mathrm{P}=0.0103 *$ & $\mathrm{P}_{\mathrm{H}}=0.2987$ \\
\hline 30) "Dark chambered mat" & $\mathrm{P}=0.2736$ & $\mathrm{P}_{\mathrm{H}}=3.0744$ \\
\hline 31) Thin grey mat & $\mathrm{P}=0.0533$ & $\mathrm{P}_{\mathrm{H}}=1.1193$ \\
\hline 32) Thin organic mat with dark grey stercomata & $\mathrm{P}=0.0247$ * & $\mathrm{P}_{\mathrm{H}}=0.6669$ \\
\hline 33) Beige thick mat with red interior & $\mathrm{P}=0.4096$ & $\mathrm{P}_{\mathrm{H}}=3.6864$ \\
\hline 34) Beige thick and smooth mat, interior brown & $\mathrm{P}=0.0044 *$ & $\mathrm{P}_{\mathrm{H}}=0.1452$ \\
\hline 35) Mat of blue flattened chambers & $\mathrm{P}=0.2191$ & $\mathrm{P}_{\mathrm{H}}=2.9904$ \\
\hline 36) White mat with lumps & $\mathrm{P}=0.1554$ & $\mathrm{P}_{\mathrm{H}}=2.6418$ \\
\hline 37) White crusty mat with coarse sediments & $\mathrm{P}=0.0096$ * & $\mathrm{P}_{\mathrm{H}}=0.2880$ \\
\hline 41) “Cemented tunnels” & $\mathrm{P}=0.0967$ & $\mathrm{P}_{\mathrm{H}}=1.9340$ \\
\hline 42) Reticulated dark tunnels & $\mathrm{P}=0.6147$ & $\mathrm{P}_{\mathrm{H}}=3.6864$ \\
\hline 43) Network of beige tunnels; horizontal tree with upright branches & $\mathrm{P}=0.4681$ & $\mathrm{P}_{\mathrm{H}}=3.6864$ \\
\hline 44) Crystal star and tunnels & $\mathrm{P}=0.0029$ * & $\mathrm{P}_{\mathrm{H}}=0.0986$ \\
\hline 45) Spider network of grey tunnels & $\mathrm{P}=0.0461 *$ & $\mathrm{P}_{\mathrm{H}}=1.1064$ \\
\hline 46) White soft tunnels & $\mathrm{P}=0.0006 *$ & $\mathrm{P}_{\mathrm{H}}=0.0216 *$ \\
\hline
\end{tabular}




\begin{tabular}{|c|c|c|c|}
\hline 49) "Fla & & $\mathrm{P}=0.0065 *$ & $\mathrm{P}_{\mathrm{H}}=0.2015$ \\
\hline 51) Horr & & $\mathrm{P}=0.6139$ & $\mathrm{P}_{\mathrm{H}}=3.6864$ \\
\hline 65) Anas & na-like & $\mathrm{P}=0.4104$ & $\mathrm{P}_{\mathrm{H}}=3.6864$ \\
\hline 68) Hori & ull of stercomata & $\mathrm{P}=0.9004$ & $\mathrm{P}_{\mathrm{H}}=3.6864$ \\
\hline M16) $\mathrm{Cr}$ & & $\mathrm{P}=0.3645$ & $\mathrm{P}_{\mathrm{H}}=3.6450$ \\
\hline C) Iden & ciated species. & & \\
\hline Group 1 & - 6) Tholosina-l & & \\
\hline & - 19) Chondrod & & \\
\hline Group2 & - 2) Hemispherc & & \\
\hline & - 5) Tholosina s & & \\
\hline & - 8) Placopsilin & & \\
\hline & - 21) Area cove & bers linked wi & e tubes \\
\hline & - 36) White mat & & \\
\hline & - 65) Anastomo & & \\
\hline
\end{tabular}


Figures

Figure 1.

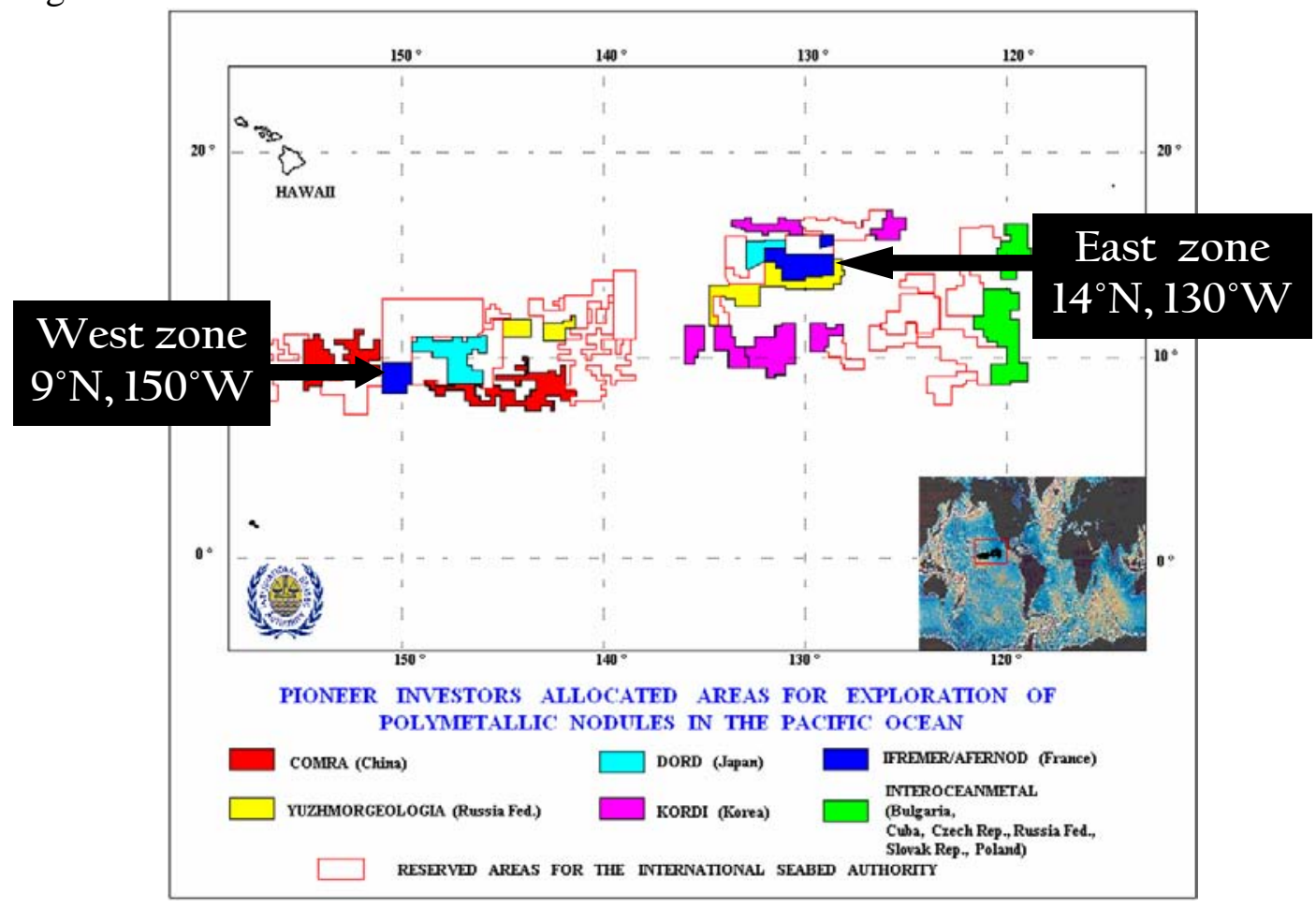


Figure 2.

SeaWiFs Chl. a: 1998-2003

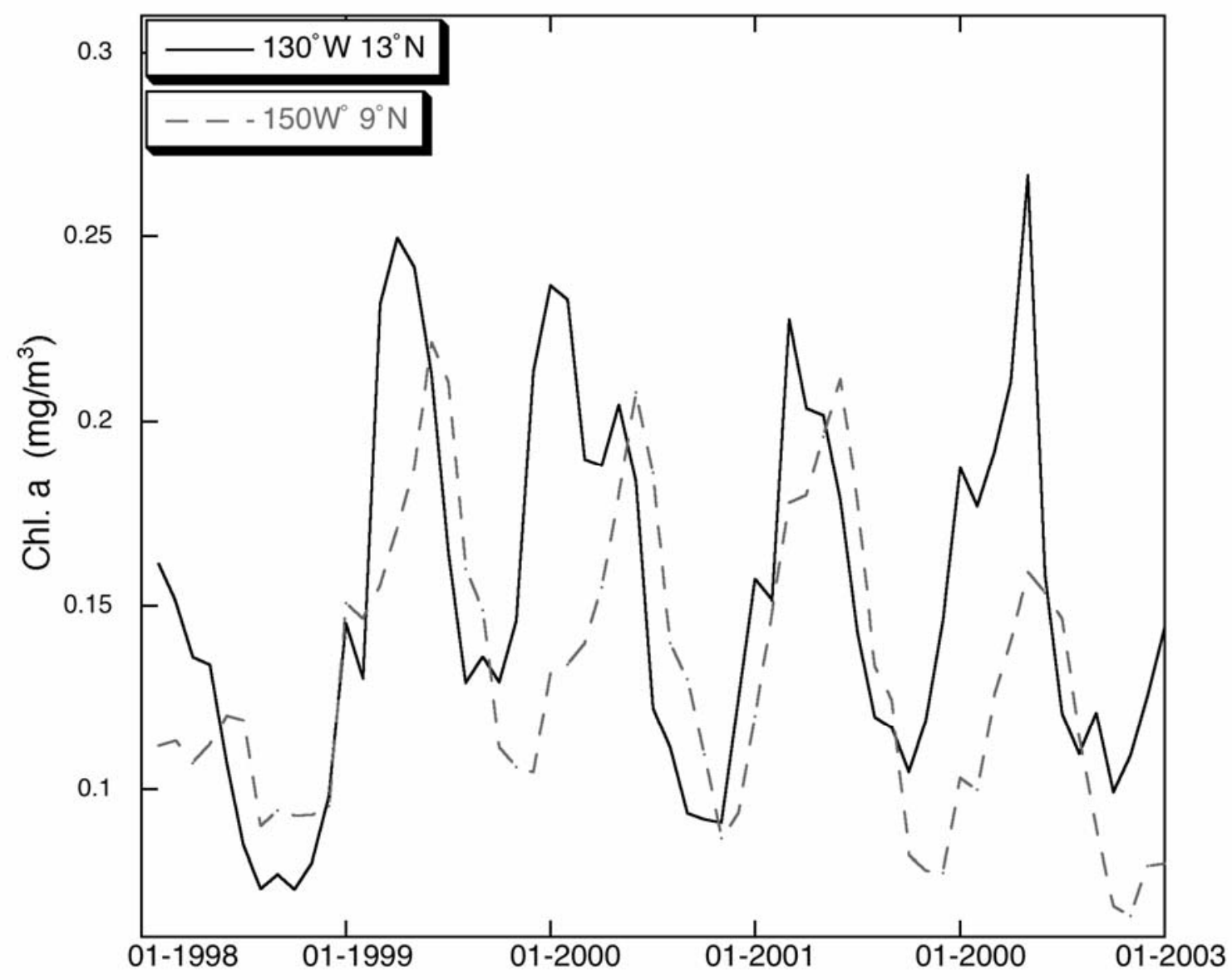


Figure 3.

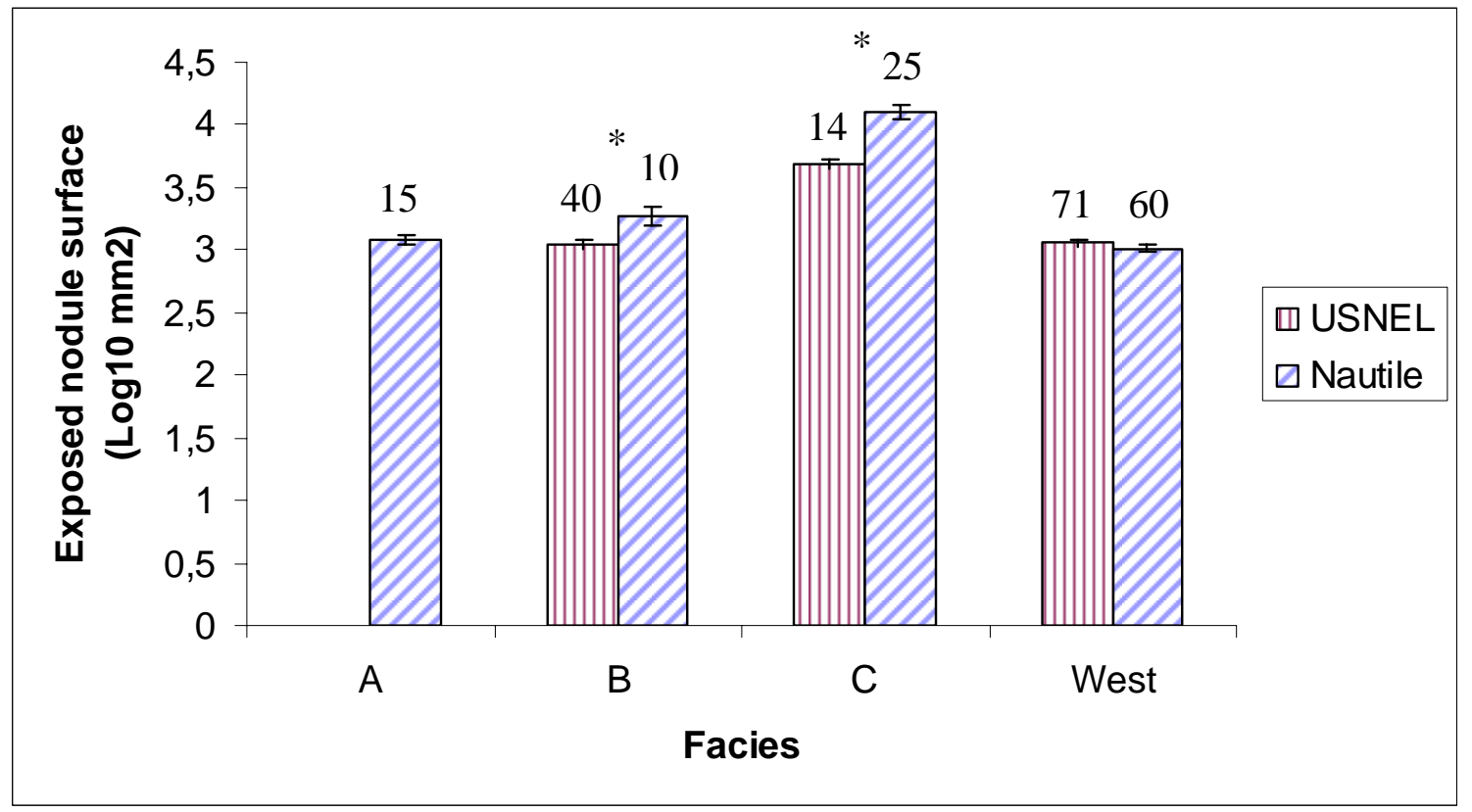


Figure 4.

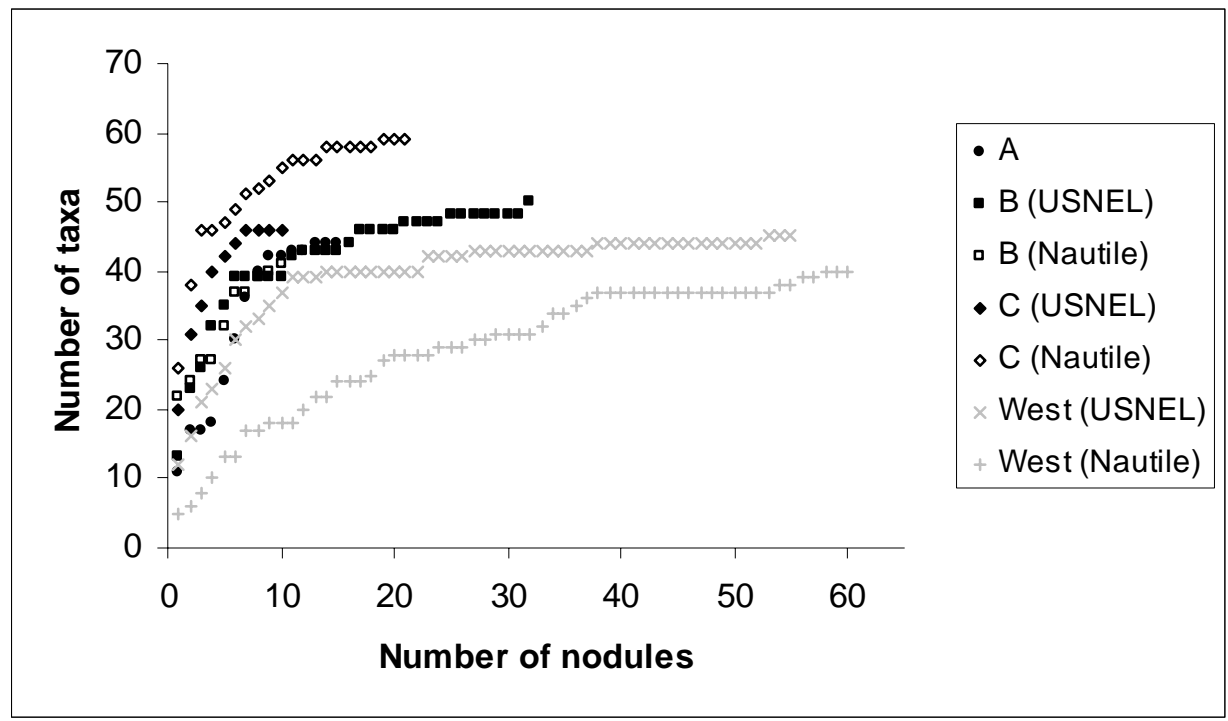


Figure 5.
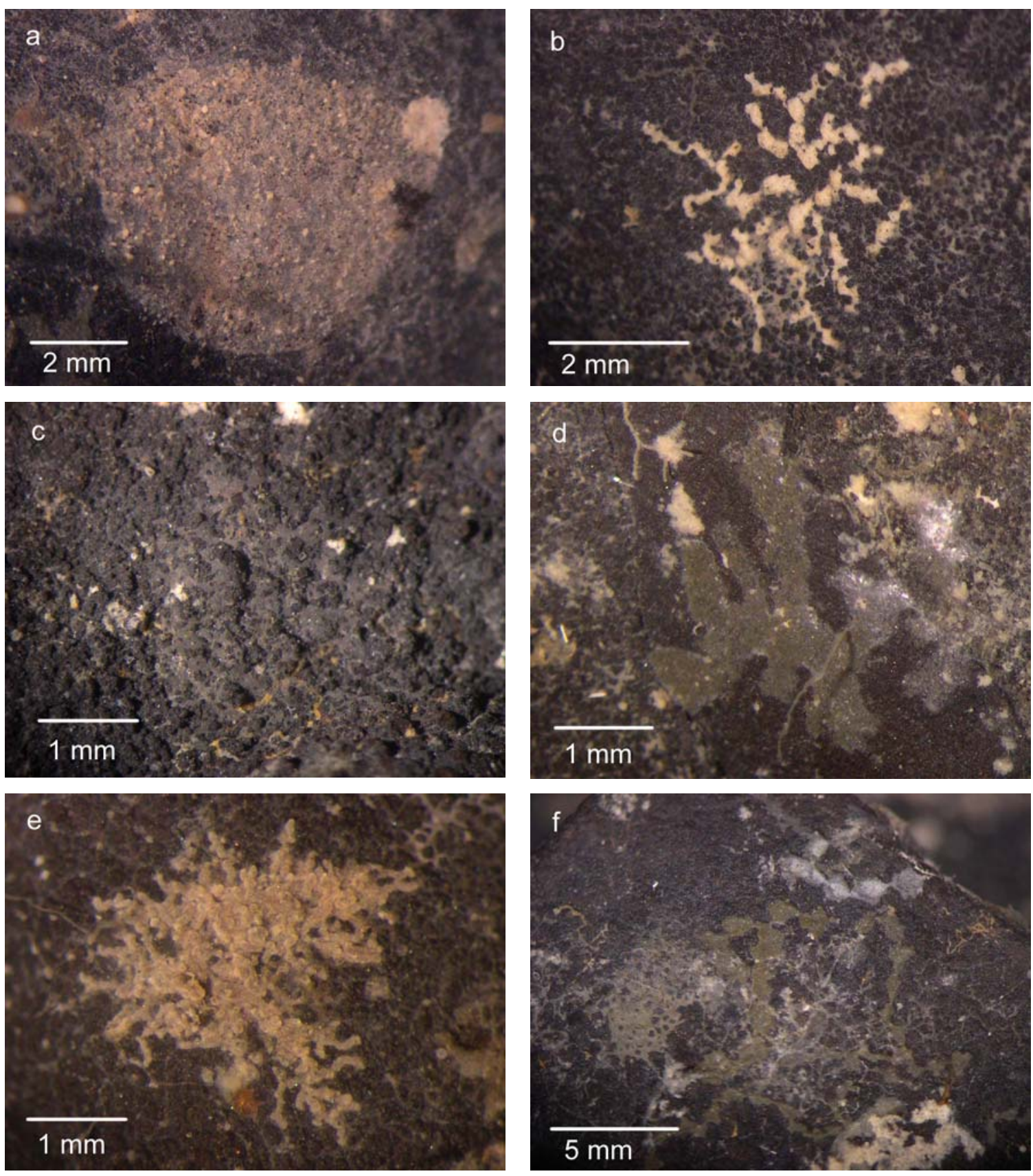

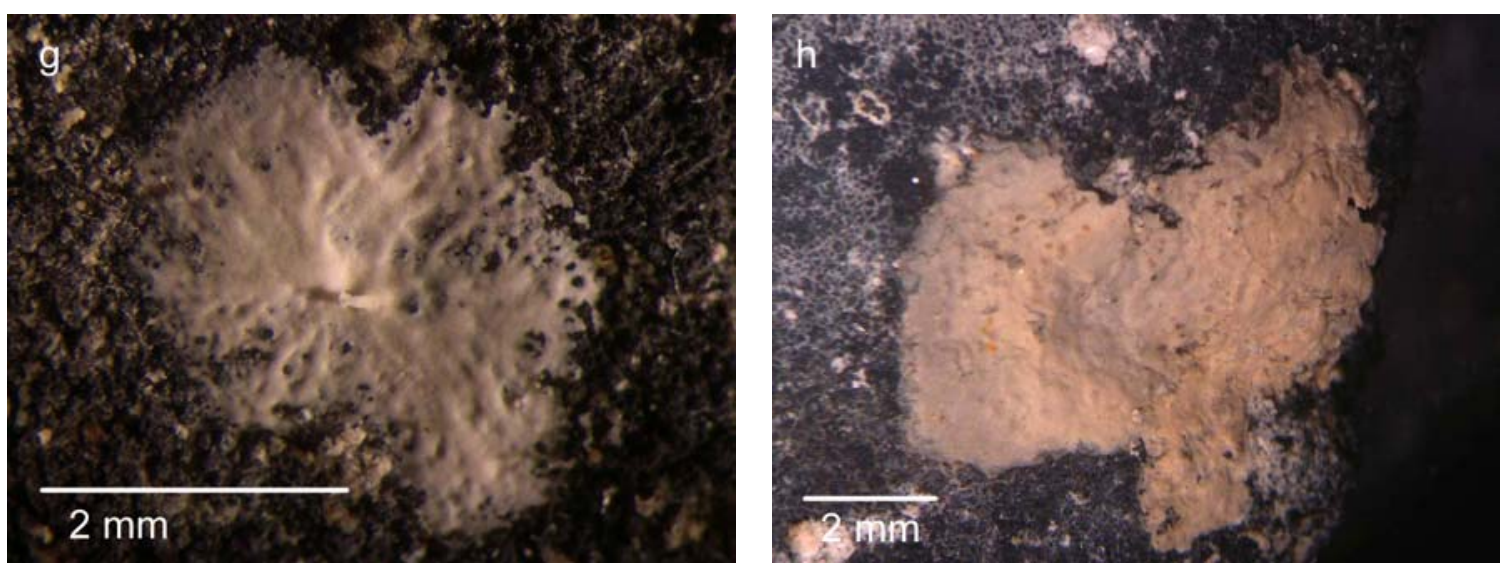
Figure 6.

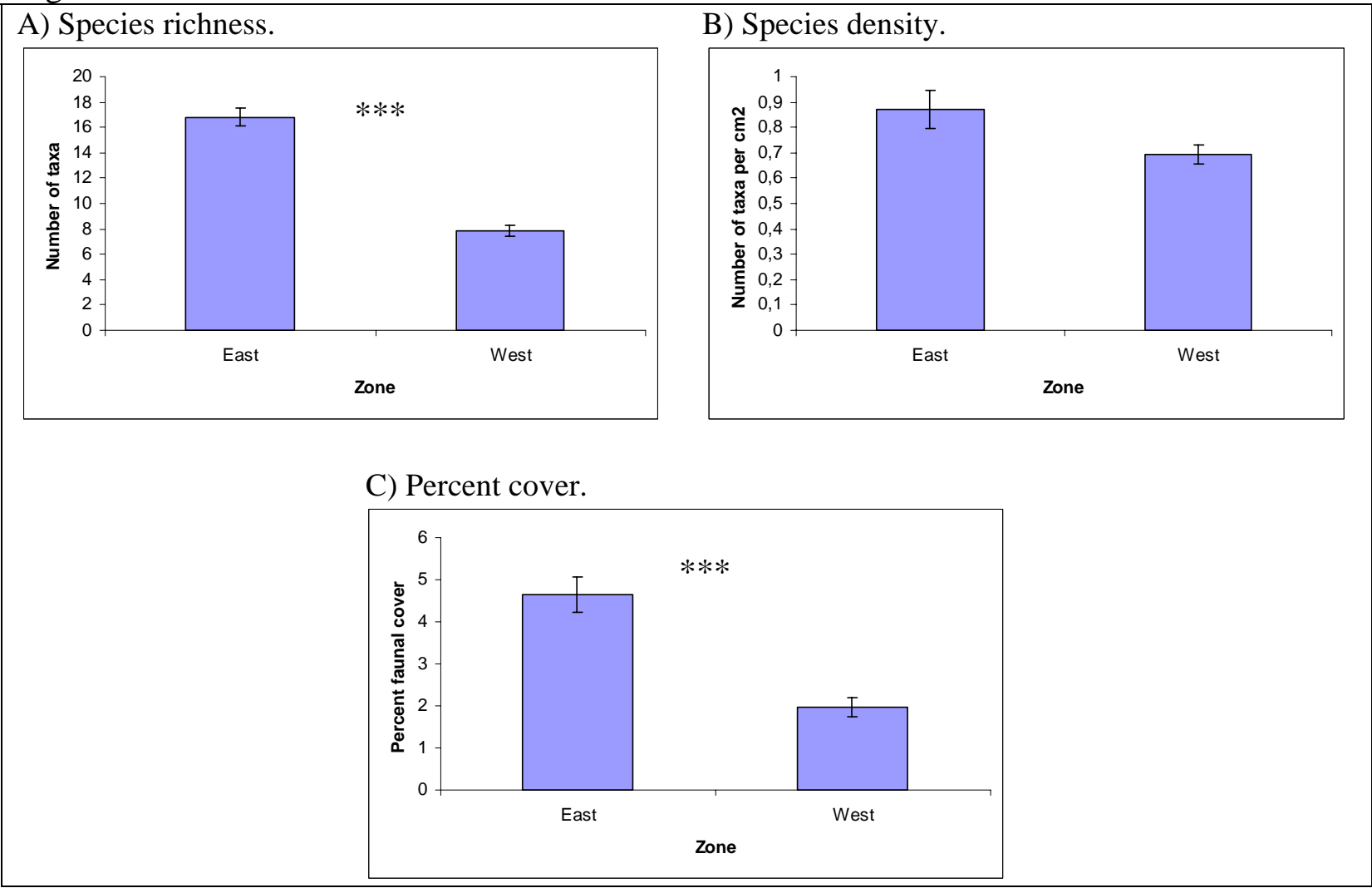


Figure 7.

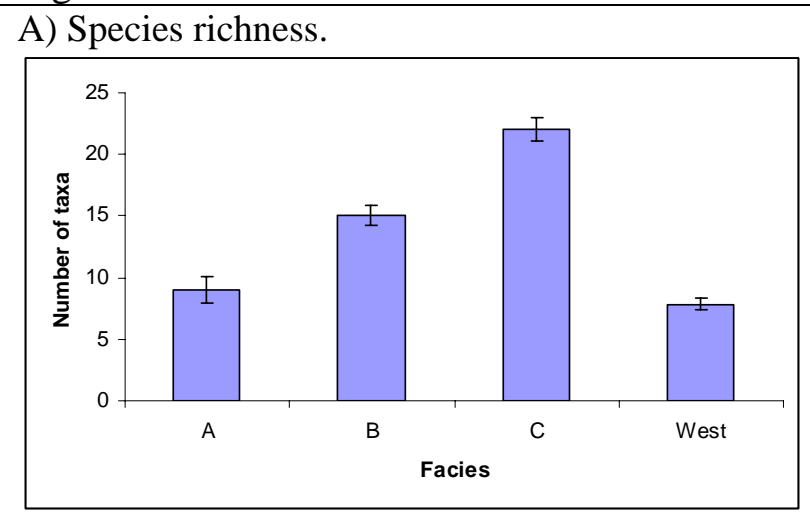

B) Species density.

C) Percent cover.

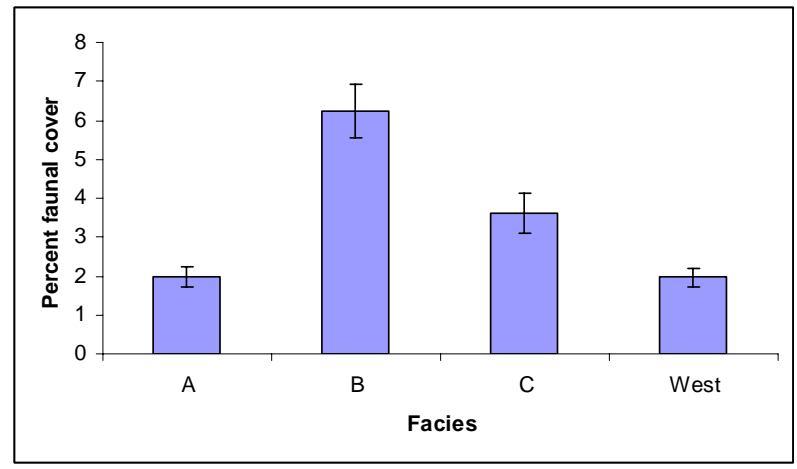


Figure 8.

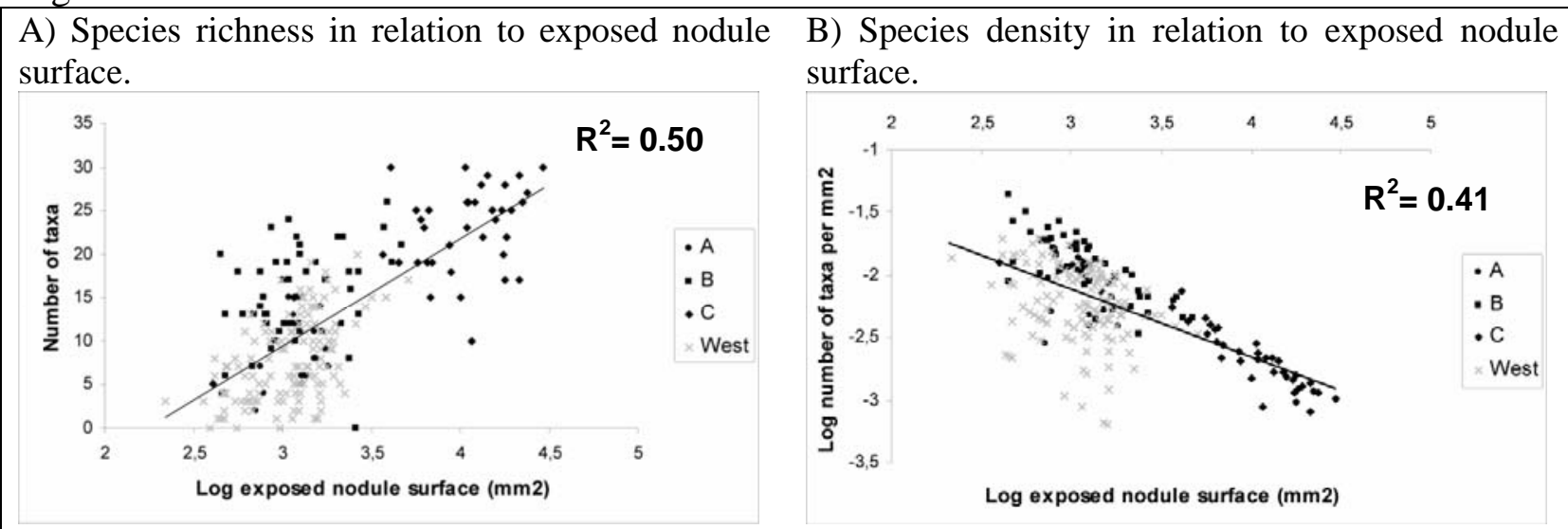

C) Percent cover in relation to exposed nodule surface.

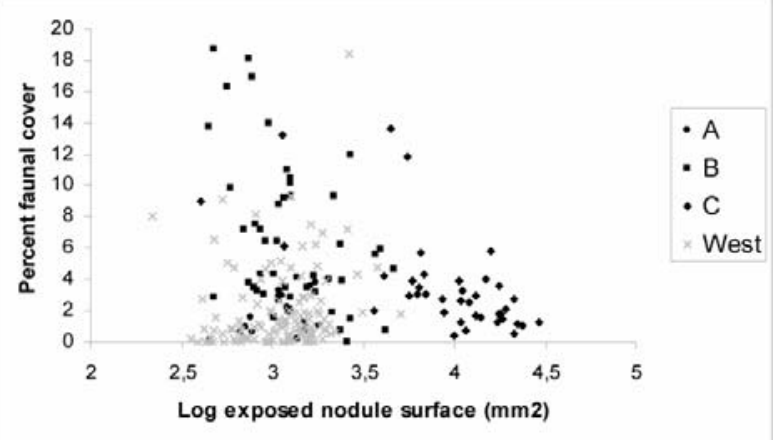


Figure 9.

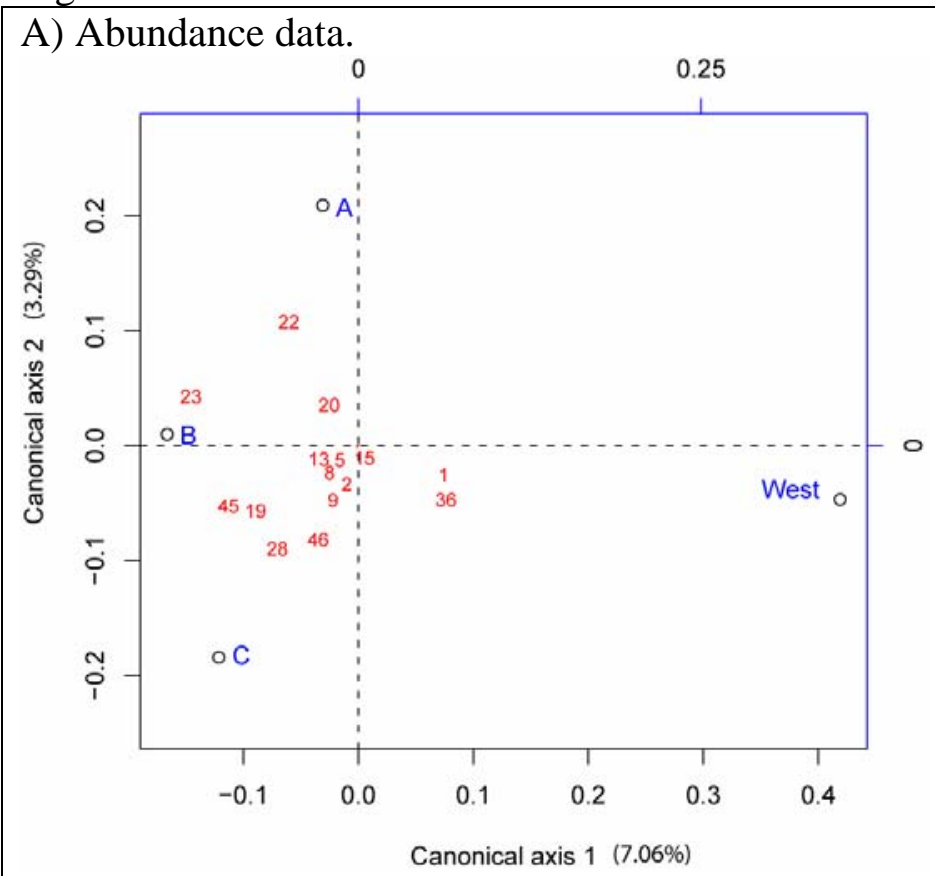

B)Presence/absence data.

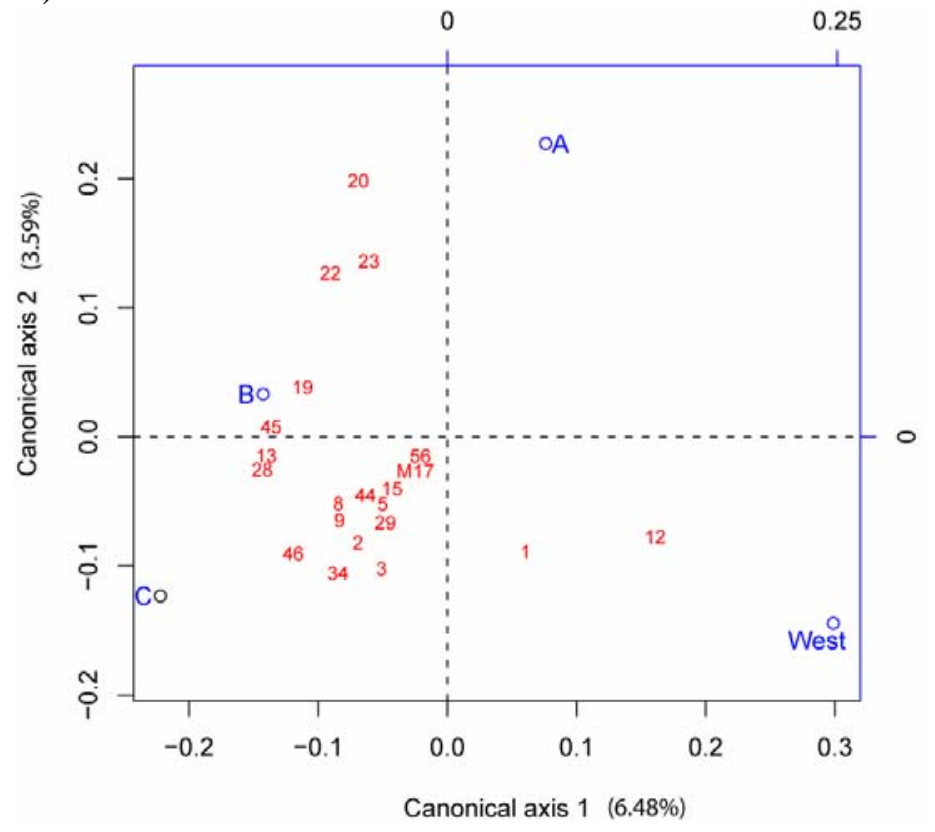




\section{Figure captions}

Figure 1. Map of the equatorial North Pacific Ocean showing the east and west zones sampled during the present study.

Figure 2. Comparison of surface chlorophyll $a$ concentrations for $5^{\circ}$ boxes around the east and west zones sampled during the present study. Monthly mean surface chlorophyll $a$ derived from SeaWiFS ocean color data.

Figure3. Nodule surface area (exposed above sediment line) for the two sampling methods, USNEL box core and the submersible Nautile, for nodules of facies B (50 nodules), C (39 nodules) and west (131 nodules). Numbers of nodules are indicated over bars. Error bars indicate SD. The non-parametric Wilcoxon/Kruskal-Wallis test was used to test differences between the two sampling methods. ${ }^{*} \alpha=0.05$. Facies $B$ : $\mathrm{Z}=1.96, \mathrm{p}=0$,002. Facies $\mathrm{C}: \mathrm{Z}=1.96, \mathrm{p}=0,03$. Facies west: $\mathrm{Z}=1.96, \mathrm{p}=0,32$. Facies $\mathrm{C}$ grouped alone and then, facies $\mathrm{A}, \mathrm{B}$ and west grouped together according to the Tukey test when nodules of the same facies collected using both sampling methods were pooled together $\left(\chi \mathrm{PP}_{0.05,3}^{2}=7.815, \mathrm{p}<0.0001\right)$.

Figure 4. Accumulation curves of taxa for the number of nodules in each facies. Nodules were collected using two sampling methods: USNEL box core and the submersible Nautile.

Figure 5. Some of the most common species living on nodule surfaces. a) Very thin muddy patches with komokiacean-like chambers; b) Tumidotubus sp.; c) Thin grey mat; d) Thin organic mat with dark grey stercomata; e) Chondrodapis hessleri; f) "Flattened chambers"; g) "White crust"; h) Beige thick and smooth mat, interior brown

Figure 6. Comparison at the regional scale of mean species richness (A), species density (B) and percent cover (C) using all 235 nodules analyzed. Error bars indicate standard error. $* \alpha=0.05, * * \alpha=0.01, * * *<0.001$. Species richness $\left(t_{0.05(2), \infty}=\mathrm{Z}=1.96\right.$, $\mathrm{p}=0.0000)$ and percent faunal cover PP $(t \quad 0.05(2), \infty=\mathrm{Z}=1.96, \mathrm{p}<0.0001)$ were significantly different between the two zones. Only species density $\left(t_{0.05(2), \infty}=\mathrm{Z}=\right.$ 1.96, $\mathrm{p}=0.5364$ ) was similar between the two.

Figure 7. Comparison at the facies scale of mean species richness (A), species density (B) and percent cover (C) using all 235 nodules analyzed. Error bars indicate standard error of the mean. All tests show significant differences between facies $\left(\chi \mathrm{PP}_{0.05,3}^{2}=\right.$ 7.815, $\mathrm{p}<0.0001)$.

Figure 8. Regression of species richness (A), species density (B) and percent cover (C) as a function of exposed nodule surface for the 235 nodules analyzed. 
Figure 9. Redundancy canonical analysis (RDA) of Hellinger-transformed abundance data (A) (42 species, RPPPPPPPPPPPPPP ${ }^{2}=0.054, \mathrm{p}=0.0005$ ) and presence/absence data (B) (62 species, $\left.\mathrm{R}^{2}=0.063, \mathrm{p}=0.0001\right)$ from 60 randomly-chosen nodules (15 nodules/facies). Nodules without fauna were excluded from the analysis. \% of variance explained by each axis indicated between parentheses. Numbers refer to species numbers as detailed in Table 5 . Only taxa for which $>10 \%$ of variance is explained by facies type are shown. 9999 permutations were realized for every test. 
